\title{
Estimation of medium effects on equilibrium constants in moderate and high ionic strength solutions at elevated temperatures by using specific interaction theory (SIT): Interaction coefficients involving $\mathrm{Cl}, \mathrm{OH}^{-}$and $\mathrm{Ac}^{-}$up to $200^{\circ} \mathrm{C}$ and 400 bars Yongliang Xiong*
}

\author{
Address: Sandia National Laboratories, Carlsbad Programs Group, 4100 National Parks Highway, Carlsbad, NM 88220, USA \\ Email: Yongliang Xiong* - yxiong@sandia.gov \\ * Corresponding author
}

Published: 23 May 2006

Geochemical Transactions 2006, 7:4 doi:10.1186/1467-4866-7-4

This article is available from: http://www.geochemicaltransactions.com/content/7///4

(c) 2006 Xiong; licensee BioMed Central Ltd.

This is an Open Access article distributed under the terms of the Creative Commons Attribution License (http://creativecommons.org/licenses/by/2.0), which permits unrestricted use, distribution, and reproduction in any medium, provided the original work is properly cited.
Accepted: 28 March 2006

Accepted: 23 May 2006

\begin{abstract}
In this study, a series of interaction coefficients of the Brønsted-Guggenheim-Scatchard specific interaction theory (SIT) have been estimated up to $200^{\circ} \mathrm{C}$ and 400 bars. The interaction coefficients involving $\mathrm{Cl}^{-}$estimated include $\varepsilon\left(\mathrm{H}^{+}, \mathrm{Cl}\right), \varepsilon\left(\mathrm{Na}^{+}, \mathrm{Cl}\right), \varepsilon\left(\mathrm{Ag}^{+}, \mathrm{Cl}\right), \varepsilon\left(\mathrm{Na}^{+}, \mathrm{AgCl}_{2}^{-}\right), \varepsilon\left(\mathrm{Mg}^{2+}, \mathrm{Cl}^{-}\right)$, $\varepsilon\left(\mathrm{Ca}^{2+}, \mathrm{Cl}^{-}\right), \varepsilon\left(\mathrm{Sr}^{2+}, \mathrm{Cl}^{-}\right), \varepsilon\left(\mathrm{Ba}^{2+}, \mathrm{Cl}^{-}\right), \varepsilon\left(\mathrm{Sm}^{3+}, \mathrm{Cl}^{-}\right), \varepsilon\left(\mathrm{Eu}^{3+}, \mathrm{Cl}^{-}\right), \varepsilon\left(\mathrm{Gd}^{3+}, \mathrm{Cl}^{-}\right)$, and $\varepsilon\left(\mathrm{GdAc}^{2+}, \mathrm{Cl}^{-}\right)$. The interaction coefficients involving $\mathrm{OH}^{-}$estimated include $\varepsilon\left(\mathrm{Li}^{+}, \mathrm{OH}^{-}\right), \varepsilon\left(\mathrm{K}^{+}, \mathrm{OH}^{-}\right), \varepsilon\left(\mathrm{Na}^{+}, \mathrm{OH}^{-}\right)$, $\varepsilon\left(\mathrm{Cs}^{+}, \mathrm{OH}^{-}\right), \varepsilon\left(\mathrm{Sr}^{2+}, \mathrm{OH}^{-}\right)$, and $\varepsilon\left(\mathrm{Ba}^{2+}, \mathrm{OH}^{-}\right)$. In addition, the interaction coefficients of $\varepsilon\left(\mathrm{Na}^{+}, \mathrm{Ac}^{-}\right)$ and $\varepsilon\left(\mathrm{Ca}^{2+}, \mathrm{Ac}^{-}\right)$have also been estimated. The bulk of interaction coefficients presented in this study has been evaluated from the mean activity coefficients. A few of them have been estimated from the potentiometric and solubility studies.

The above interaction coefficients are tested against both experimental mean activity coefficients and equilibrium quotients. Predicted mean activity coefficients are in satisfactory agreement with experimental data. Predicted equilibrium quotients are in very good agreement with experimental values.

Based upon its relatively rapid attainment of equilibrium and the ease of determining magnesium concentrations, this study also proposes that the solubility of brucite can be used as a $\mathrm{pH}(\mathrm{pcH})$ buffer/sensor for experimental systems in $\mathrm{NaCl}$ solutions up to $200^{\circ} \mathrm{C}$ by employing the predicted solubility quotients of brucite in conjunction with the dissociation quotients of water and the first hydrolysis quotients of $\mathrm{Mg}^{2+}$, all in $\mathrm{NaCl}$ solutions.
\end{abstract}

\section{Introduction}

Knowledge of medium effects on thermodynamics in concentrated solutions is fundamentally important to the thermodynamic modeling in many fields ranging from experimental systems in aqueous solutions to hydrothermal ore deposits of the natural systems. In two recent, detailed reviews $[1,2]$, several models which can handle moderate to high ionic strength solutions are surveyed. Those models surveyed include the Pitzer equations [3], the Brønsted-Guggenheim-Scatchard specific interaction theory (SIT) [4-6], the Bromley model [7], and the Helgeson activity coefficient model [8]. In addition, although not surveyed in the above two reviews, the commonly 
used B dot equation [9] in geochemistry is valid to the ionic strength of $1.0 \mathrm{~m}$ at most [10].

Because they have a large number of adjustable parameters, the Pitzer equations are excellent in fitting the experimental data in highly concentrated solutions as well as in diluted solutions [11]. Therefore, the Pitzer equations can accurately reproduce activity coefficients and other thermodynamic properties at high ionic strength up to the saturation of most salts.

The SIT model is most useful in the ionic strength range up to 3.5-4.0 m [e.g, [12-15]], and successful applications of the SIT model at $25^{\circ} \mathrm{C}$ in $\mathrm{NaCl}$ solutions up to the saturation of halite have also been demonstrated [e.g., [16]]. The SIT model can be regarded as a simplified version of the Pitzer formalism without consideration of triple interactions and interactions between ions of the same charge sign. Therefore, the Pitzer formalism is certainly superior to the SIT model. The shortcoming of the SIT model is its rather low accuracy in reproduction of mean activity coefficients in comparison with Pitzer model [2]. However, the error is usually less than $10 \%$ at ionic strength up to $6-10 \mathrm{~m}$ at $25^{\circ} \mathrm{C}[2]$.

The Bromley model is similar to the SIT model, but it takes the concentration dependence of second virial coefficients into consideration. Accordingly, the Bromley model fits experimental data slightly better than the SIT model does [2]. However, Wang et al. [2] also pointed out that even though the Bromley model has a more complicated analytical form than the SIT model, both the Bromley and SIT models reproduce experimental data with practically equal quality according to their extensive evaluation.

As stated by Grenthe et al. [1] and Wang et al. [2], the Helgeson activity coefficient model is actually a oneparameter equation, and it has the same accuracy as that of the SIT model. Nevertheless, the validity of the assumptions of the Helgeson activity coefficient model is not clear. Furthermore, the usage of different values of the ion size parameters $\left(a_{i}\right)$ for different ions and electrolytes is considered as an obvious drawback of the model, because it creates difficulties in employing the model to mixtures of electrolytes, and results in the violation of cross-differential relations $[1,2]$.

In investigations of systems where complex formation takes place, a method of constant ionic medium is usually adopted. As pointed out by Wang et al. [2], there are difficulties in determination of activity coefficients of reaction species in a constant ionic medium. Usually only a value of equilibrium constant in a certain medium can be determined, and the number of equilibrium constants obtained is generally small. Second, the accuracy of equilibrium constants is relatively low in comparison with that of mean activity coefficients and osmotic coefficients. Accordingly, owing to these two facts, it is sensible to use an activity model with fewer parameters when dealing with experimental equilibrium constants, as it is often impractical to determine more than one or two empirical parameters from a small number of such constants with limited accuracy. The Pitzer equations are widely utilized to treat a number of data with an accuracy better than 0.5 relative percent. However, when describing equilibrium constants as a function of ionic strength, the Pitzer formalism commonly has an accuracy up to a relative percentage of 10-50, which results in such an ill-conditioned assignment that a unique set of the Pitzer parameters cannot be determined [2].

Grenthe et al. [1] provided detailed examples for comparison of the SIT model with the Pitzer formalism in the description of medium effects on equilibrium constants at $25^{\circ} \mathrm{C}$. Their comparison indicates that the less-parameterized SIT model gives quite reasonable estimations of equilibrium constants in different media at various ionic strengths, provided that the necessary interaction coefficients are known. They concluded that the simple oneparameter SIT model reproduces the experimental equilibrium data very well.

The above brief descriptions suggest that when the required Pitzer parameters are evaluated accurately from extensive data, the Pitzer model is a preferred, standard method in presentation of experimentally determined thermodynamic properties of electrolytes. However, the SIT model, because of its advantages in mathematical simplicity and its less-parameterized nature, may find applications when the experimental data are less extensive, or the accuracy provided by the SIT model is deemed to be satisfactory, or in systems where complex formation occurs. This is especially true in cases in treatment of equilibrium constants. Consequently, the SIT model has the potential to become a useful method to estimate medium effects on equilibrium constants in concentrated solution in high temperature aqueous geochemistry and chemistry.

However, few studies have addressed SIT interaction coefficients at elevated temperatures. Giffaut et al. [17] estimated the interaction coefficients of $\varepsilon\left(\mathrm{H}^{+}, \mathrm{Cl}^{-}\right)$, and $\varepsilon\left(\mathrm{Sr}^{2+}\right.$, $\left.\mathrm{Cl}^{-}\right)$up to $70^{\circ} \mathrm{C}$, and $\varepsilon\left(\mathrm{Li}^{+}, \mathrm{Cl}^{-}\right), \varepsilon\left(\mathrm{Na}^{+}, \mathrm{Cl}^{-}\right)$, and $\varepsilon\left(\mathrm{K}^{+}, \mathrm{Cl}^{-}\right)$ up to $150^{\circ} \mathrm{C}$. Bretti et al. [18] estimated the interaction coefficients of $\varepsilon\left(\mathrm{H}^{+}, \mathrm{Cl}^{-}\right)$up to $60^{\circ} \mathrm{C}$. It is clear that interaction coefficients of $\mathrm{Cl}^{-}$with geochemically important metal ions such as $\mathrm{Mg}^{2+}, \mathrm{Ca}^{2+}$, and $\mathrm{Ba}^{2+}$ are lacking, and so are interaction coefficients with $\mathrm{OH}^{-}$. In addition, those interaction coefficients mentioned in the above studies were not tested against experimental data. Therefore, the 
main objective of this study is to estimate a series of internally consistent interaction coefficients involving $\mathrm{Cl}^{-}$and $\mathrm{OH}^{-}$up to $200^{\circ} \mathrm{C}$. Interaction coefficients involving $\mathrm{Cl}^{-}$are especially of geochemical importance because of its ubiquity in geological fluids.

The intent of this study and future studies of this aspect is to provide experimental aqueous geochemists and hightemperature geochemical modelers a simple means in assessing ionic medium effects on equilibrium constants of various reactions including complex formation reactions at elevated temperatures at ionic strength higher than $1.0 \mathrm{~m}$. Currently, most experimental work on equilibrium constants at elevated temperatures is usually limited up to ionic strength of $1.0 \mathrm{~m}$, which is the limit of the $\mathrm{B}$ dot equation. It should be stressed that the Pitzer formalism should be used to treat high precision activity and osmotic coefficients at elevated temperatures, if they are available.

\section{Estimation of interaction coefficients and their temperature dependence expressions Interaction coefficients estimated from mean activity coefficients}

In this study, the bulk of interaction coefficients are evaluated from mean activity coefficients of electrolytes. The analytical expression for evaluation of interaction coefficients from mean activity coefficient data of electrolytes, using $\gamma_{ \pm, \mathrm{HCl}}$ as an example, is as follows [14]:

$2 \log \gamma_{ \pm, \mathrm{HCl}}=-\left(\mathrm{Z}_{+}\right)^{2} \mathrm{D}+\varepsilon\left(\mathrm{H}^{+}, \mathrm{Cl}^{-}\right) \mathrm{m}_{\mathrm{HCl}}-\left(\mathrm{Z}_{-}\right)^{2} \mathrm{D}+\varepsilon\left(\mathrm{Cl}^{-}, \mathrm{H}^{+}\right)$ $\mathrm{m}_{\mathrm{HCl}}$ (1)

where $\mathrm{D}$ is the Debye-Hückel term given by the following expression:

$$
\mathrm{D}=\frac{A_{\gamma} \sqrt{I}}{1+\rho \sqrt{I}}
$$

where $A_{\gamma}$ is Debye-Hückel slopes for activity coefficient, $Z_{+}$ and $Z_{-}$are charges of the cation and anion, respectively; $\rho$ the minimum distance of approach between ions [12], and $I$ ionic strength on the molal scale. Different values ranging from $1.0[5]$ to $1.6[19]$ have been proposed for $\rho$. In this study, $\rho$ is assigned to be 1.5 to follow the convention of Scatchard [6] (p. 145), and numerous studies have adopted this value [e.g., [2,12-14,18,20]]. However, as stated by Grenthe et al. [14], the variation in $\tilde{\mathrm{n}}\left(\mathrm{Ba}_{\mathrm{j}}\right.$ term in [14]) values used in the Debye-Hückel term does not represent an uncertainty range, but rather indicates covariation of the parameters $\tilde{n}$ and $\varepsilon(\mathrm{j}, \mathrm{k})$ such that several different combinations of these parameters may reproduce equally well the measured mean activity coefficients of a given electrolyte. The Debye-Hückel slopes for activity coefficient $\left(A_{\gamma}\right)$ are temperature and pressure dependent.
In this study, the Debye-Hückel slopes for activity coefficient at various temperatures at 1 bar (below $100^{\circ} \mathrm{C}$ ) and saturated vapor pressures $\left(\mathrm{P}_{\mathrm{SAT}}\right)\left(100^{\circ} \mathrm{C}\right.$ and above $)$ are from Helgeson et al. [8], and those at various temperatures at the constant pressure of 200 or 400 bars are from Bradley and Pitzer [21]. The Debye-Hückel slopes from Helgeson et al. [8] at 1 bar and saturated vapor pressures are precise to four decimal places, and those from Bradley and Pitzer [21] at various pressures including saturated vapor pressures are precise to three decimal places. The Debye-Hückel slopes from Helgeson et al. [8] at $0^{\circ} \mathrm{C}-$ $40^{\circ} \mathrm{C}$ at 1 bar are identical to those of Bradley and Pitzer [21] in the same temperature range at saturated vapor pressures. The Debye-Hückel slopes from these two sources at saturated vapor pressures differ by up to 0.002 in the temperature range from $50^{\circ} \mathrm{C}$ to $200^{\circ} \mathrm{C}$.

Rearranging Eq. (1), we have

$\log \gamma_{ \pm, \mathrm{HCl}}+\mathrm{D}=\varepsilon\left(\mathrm{H}^{+}, \mathrm{Cl}^{-}\right) \mathrm{m}_{\mathrm{HCl}}$

According to Eq. (3), by plotting $\mathrm{m}_{\mathrm{HCl}}$ versus $\log \gamma_{ \pm, \mathrm{HCl}}+$ $\mathrm{D}$, the slope will be $\varepsilon\left(\mathrm{H}^{+}, \mathrm{Cl}^{-}\right)$, and the linearity of fitting will indicate the ionic strength range for validity of $\varepsilon\left(\mathrm{H}^{+}\right.$, $\mathrm{Cl}^{-}$). As an example of such evaluation, the plot at $25^{\circ} \mathrm{C}$, $75^{\circ} \mathrm{C}, 125^{\circ} \mathrm{C}$ and $175^{\circ} \mathrm{C}$ is illustrated in Figure 1.

By following the above methodology, interaction coefficients are systematically evaluated (Table 1 ). The interaction coefficients of $\varepsilon\left(\mathrm{H}^{+}, \mathrm{Cl}^{-}\right)$at saturated vapor pressures $\left(\mathrm{P}_{\mathrm{SAT}}\right)$ are evaluated from the mean activity coefficients of $\mathrm{HCl}$ from the compilation of Robinson and Stokes [22], the electromotive force measurements of Greeley et al. [23] and isopiestic investigations of Holmes et al. [24]. The interaction coefficients of $\varepsilon\left(\mathrm{H}^{+}, \mathrm{Cl}^{-}\right)$at 400 bars are evaluated from the mean activity coefficients of $\mathrm{HCl}$ from the isopiestic data of Holmesetal. [24]. The comparison of $\varepsilon\left(\mathrm{H}^{+}, \mathrm{Cl}^{-}\right)$at $\mathrm{P}_{\mathrm{SAT}}$ with those at 400 bars reveals that there is a systematic increase in interaction coefficient with pressure, although such increase is within the uncertainty of evaluation.

Interaction coefficients of $\varepsilon\left(\mathrm{Na}^{+}, \mathrm{Cl}^{-}\right)$, from $0^{\circ} \mathrm{C}$ to $200^{\circ} \mathrm{C}$ at $\mathrm{P}_{\mathrm{SAT}}$ are evaluated from the experimental data of Gibbard et al. [25]

Interaction coefficients of $\varepsilon\left(\mathrm{Mg}^{2+}, \mathrm{Cl}^{-}\right), \varepsilon\left(\mathrm{Ca}^{2+}, \mathrm{Cl}^{-}\right), \varepsilon\left(\mathrm{Sr}^{2+}\right.$, $\left.\mathrm{Cl}^{-}\right)$, and $\varepsilon\left(\mathrm{Ba}^{2+}, \mathrm{Cl}^{-}\right)$are evaluated from isopiestic studies of Holmes et al. [25] and Holmes and Mesmer [27]. Three sets of interaction coefficients of $\varepsilon\left(\mathrm{Mg}^{2+}, \mathrm{Cl}^{-}\right), \varepsilon\left(\mathrm{Ca}^{2+}, \mathrm{Cl}^{-}\right)$, $\varepsilon\left(\mathrm{Sr}^{2+}, \mathrm{Cl}^{-}\right)$, and $\varepsilon\left(\mathrm{Ba}^{2+}, \mathrm{Cl}^{-}\right)$are evaluated three constant pressures (i.e., $\mathrm{P}_{\mathrm{SAT}}, 200$ bars, and 400 bars). Similarly to $\varepsilon\left(\mathrm{H}^{+}, \mathrm{Cl}^{-}\right)$, there is a systematic increase in interaction coefficient with pressure, although such increase is within the uncertainty of evaluation. 


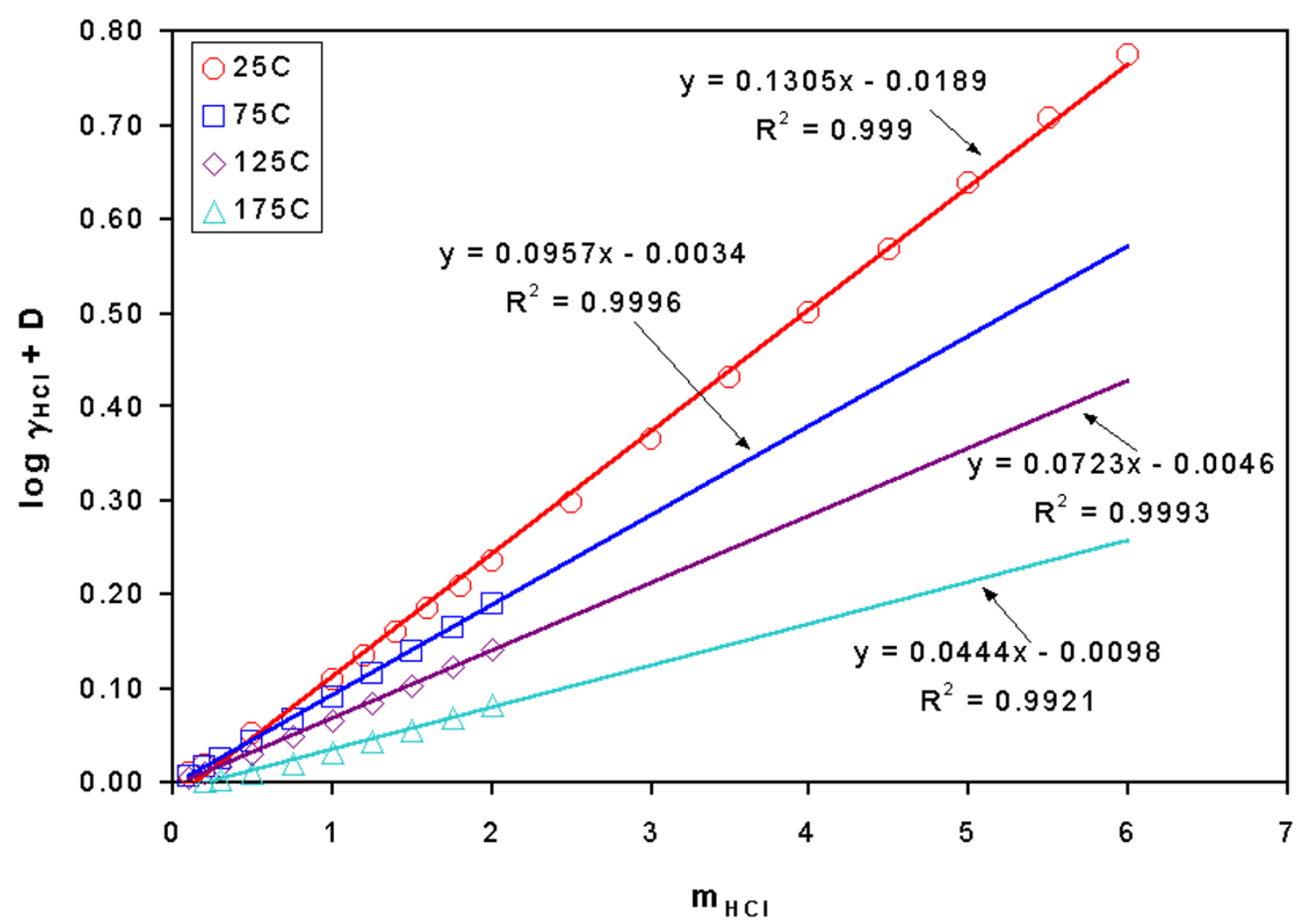

Figure I

A plot of $\log \gamma_{ \pm, \mathrm{HCl}}+\mathrm{D}$ versus $\mathrm{m}_{\mathrm{HCl}}$ at $25^{\circ} \mathrm{C}, 75^{\circ} \mathrm{C}, 125^{\circ} \mathrm{C}$ and $175^{\circ} \mathrm{C}$. The slope is the interaction coefficient $\varepsilon\left(\mathrm{H}^{+}, \mathrm{Cl}^{-}\right)$.

Roy et al. [28] experimentally determined activity coefficients of the $\mathrm{HCl}+\mathrm{GdCl}_{3}+\mathrm{H}_{2} \mathrm{O}$ system up to $55^{\circ} \mathrm{C}$ by measuring electromotive force at ionic strength up to 2.0 $\mathrm{m}$. Based upon the enthalpy [29] and heat capacity [30] data of $\mathrm{GdCl}_{3}$, they derive temperature dependence relations for the Pitzer parameters of $\mathrm{GdCl}_{3}$ to $55^{\circ} \mathrm{C}$. In the present study, mean activity coefficients of $\mathrm{GdCl}_{3}$ solutions with concentrations of $\mathrm{GdCl}_{3}$ from $0.1 \mathrm{~m}$ to $1.0 \mathrm{~m}$ up to $65^{\circ} \mathrm{C}$ at 1 bar are reproduced according the temperature dependence relations of the Pitzer parameters from Roy et al. [28]. Results above $55^{\circ} \mathrm{C}$ to $65^{\circ} \mathrm{C}$ are generated by extrapolation of the temperature dependence relations of Roy et al. [28] to $65^{\circ} \mathrm{C}$. Reproduction of mean activity coefficients of $\mathrm{GdCl}_{3}$ follows the equations defined by Pitzer and Mayorga [31] (their equations (3), (6), (9) and (11)), and the necessary Pitzer-Debye-Hückel slopes for the osmotic coefficients $\left(\mathrm{A}_{\varphi}\right)$ at temperatures of interest and at $1 \mathrm{~atm}$. are taken from Ananthaswamy and Atkinson [32]. Then, the interaction coefficients of $\varepsilon\left(\mathrm{Gd}^{3+}, \mathrm{Cl}^{-}\right)$up to $65^{\circ} \mathrm{C}$ are evaluated from the mean activity coefficients of $\mathrm{GdCl}_{3}$.
Similarly, Roy et al. [33] experimentally determined activity coefficients of the $\mathrm{HCl}+\mathrm{SmCl}_{3}+\mathrm{H}_{2} \mathrm{O}$ system up to $55^{\circ} \mathrm{C}$ by measuring electromotive force at ionic strength up to $3.0 \mathrm{~m}$. They estimated temperature dependence relations for the Pitzer parameters of $\mathrm{SmCl}_{3}$ to $55^{\circ} \mathrm{C}$ by using the enthalpy [29] and heat capacity [30] data of $\mathrm{SmCl}_{3}$. In this study, mean activity coefficients of $\mathrm{SmCl}_{3}$ solutions with concentrations of $\mathrm{SmCl}_{3}$ from $0.1 \mathrm{~m}$ to $1.0 \mathrm{~m}$ up to $65^{\circ} \mathrm{C}$ at 1 bar are reproduced according the temperature dependence relations of the Pitzer parameters from Roy et al. [33]. Then, the interaction coefficients of $\varepsilon\left(\mathrm{Sm}^{3+}, \mathrm{Cl}^{-}\right)$ up to $65^{\circ} \mathrm{C}$ are evaluated from the mean activity coefficients of $\mathrm{SmCl}_{3}$ solutions.

In a similar study, Roy et al. [34] investigated activity coefficients of the $\mathrm{HCl}+\mathrm{EuCl}_{3}+\mathrm{H}_{2} \mathrm{O}$ system up to $55^{\circ} \mathrm{C}$ by measuring electromotive force at ionic strength up to 2.0 $\mathrm{m}$. They derived temperature dependence relations for the Pitzer parameters of $\mathrm{EuCl}_{3}$ to $55^{\circ} \mathrm{C}$ according to the enthalpy [29] and heat capacity [30] data of $\mathrm{EuCl}_{3}$. In this study, mean activity coefficients of $\mathrm{EuCl}_{3}$ solutions with 
Table I: Interaction coefficients involving $\mathrm{Cl}^{-}, \mathrm{OH}^{-}$and $\mathrm{Ac}^{-}$evaluated by this study at various temperatures

\begin{tabular}{|c|c|c|c|c|c|c|c|}
\hline $\begin{array}{l}\text { Type of } \\
\text { Interaction } \\
\text { Coefficient }\end{array}$ & $\mathrm{T}, \mathrm{K}$ & Value & $2 \sigma$ of $\varepsilon$ & $\begin{array}{l}\text { Linearity of Fitting } \\
\text { (Square of Linear } \\
\text { Correlation } \\
\text { Coefficient, } R^{2} \text { ) }\end{array}$ & lonic Strength, $\mathrm{m}$ & Pressure & Experimental Data Sources for Evaluation \\
\hline \multirow[t]{10}{*}{$\varepsilon\left(\mathrm{H}^{+}, \mathrm{Cl}\right)$} & 273.15 & 0.1292 & 0.0013 & 0.9998 & $0.1-2.0$ & $\mathrm{P}_{\mathrm{SAT}}{ }^{\mathrm{A}}$ & Holmes et al. [24] \\
\hline & 298.15 & 0.1305 & 0.0022 & 0.9990 & $0.1-6.0$ & $\mathrm{P}_{\mathrm{SAT}}$ & $\begin{array}{l}\text { Robinson and Stokes [22]; Greeley et al. [23]; Holmes et al. } \\
\text { [24] }\end{array}$ \\
\hline & 348.15 & 0.0957 & 0.0013 & 0.9996 & $0.1-2.0$ & $\mathrm{P}_{\mathrm{SAT}}$ & Holmes et al. [24] \\
\hline & 398.15 & 0.0723 & 0.0014 & 0.9993 & $0.1-2.0$ & $\mathrm{P}_{\mathrm{SAT}}$ & Holmes et al. [24] \\
\hline & 448.15 & 0.0444 & 0.0028 & 0.9921 & $0.1-2.0$ & $\mathrm{P}_{\mathrm{SAT}}$ & Holmes et al. [24] \\
\hline & 273.15 & 0.1304 & 0.0012 & 0.9998 & $0.1-2.0$ & 400 bars & Holmes et al. [24] \\
\hline & 298.15 & 0.1198 & 0.0010 & 0.9998 & $0.1-2.0$ & 400 bars & \\
\hline & 348.15 & 0.0986 & 0.0007 & 0.9999 & $0.1-2.0$ & 400 bars & \\
\hline & 398.15 & 0.0766 & 0.0007 & 0.9998 & $0.1-2.0$ & 400 bars & \\
\hline & 448.15 & 0.0512 & 0.0013 & 0.9987 & $0.1-2.0$ & 400 bars & \\
\hline \multirow[t]{8}{*}{$\varepsilon\left(\mathrm{Na}^{+}, \mathrm{Cl}^{-}\right)$} & 273.15 & 0.0312 & 0.0028 & 0.9809 & $0.5-3.5$ & $\mathrm{P}_{\mathrm{SAT}}$ & Gibbard et al. [25] \\
\hline & 298.15 & $0.047 \mid$ & 0.0017 & 0.9932 & $0.5-6.0$ & $\mathrm{P}_{\mathrm{SAT}}$ & \\
\hline & 348.15 & 0.0467 & 0.0007 & 0.9990 & $0.5-6.0$ & $\mathrm{P}_{\mathrm{SAT}}$ & \\
\hline & 373.15 & 0.0432 & 0.0005 & 0.9993 & $0.5-6.0$ & $\mathrm{P}_{\mathrm{SAT}}$ & \\
\hline & 398.15 & 0.0389 & 0.0004 & 0.9996 & $0.5-6.0$ & $\mathrm{P}_{\mathrm{SAT}}$ & \\
\hline & 423.15 & 0.0338 & 0.0003 & 0.9996 & $0.5-6.0$ & $\mathrm{P}_{\mathrm{SAT}}$ & \\
\hline & 448.15 & 0.0279 & 0.0005 & 0.9984 & $0.5-6.0$ & $P_{S A T}$ & \\
\hline & 473.15 & 0.0210 & 0.0006 & 0.9964 & $0.5-6.0$ & $P_{S A T}$ & \\
\hline \multirow[t]{3}{*}{$\varepsilon\left(\mathrm{Na}^{+}, \mathrm{AgCl}_{2}^{-}\right)$} & 373.15 & -0.02 & 0.03 & 0.9821 & $0.5-3.0$ & $\mathrm{P}_{\mathrm{SAT}}$ & Seward [4I] \\
\hline & 423.15 & -0.05 & 0.03 & 0.9807 & $0.5-3.0$ & $P_{S A T}$ & \\
\hline & 470.15 & -0.07 & 0.03 & 0.9832 & $0.5-3.0$ & $\mathrm{P}_{\mathrm{SAT}}$ & \\
\hline \multirow[t]{3}{*}{$\varepsilon\left(\mathrm{Ag}^{+}, \mathrm{Cl}^{-}\right)$} & 373.15 & 0.08 & 0.01 & 0.9842 & $0.5-3.0$ & $P_{S A T}$ & Seward [4I] \\
\hline & 423.15 & 0.11 & 0.02 & 0.9825 & $0.5-3.0$ & $\mathrm{P}_{\mathrm{SAT}}$ & \\
\hline & 470.15 & 0.13 & 0.02 & 0.9840 & $0.5-3.0$ & $P_{S A T}$ & \\
\hline \multirow[t]{18}{*}{$\varepsilon\left(\mathrm{Mg}^{2+}, \mathrm{Cl}\right)$} & 273.15 & 0.232 & 0.023 & 0.9959 & $0.3-6$ & $\mathrm{P}_{\mathrm{SAT}}$ & Holmes and Mesmer [27] \\
\hline & 298.15 & 0.209 & 0.022 & 0.9952 & $0.3-6$ & $P_{S A T}$ & \\
\hline & 323.15 & 0.191 & 0.020 & 0.9951 & $0.3-6$ & $\mathrm{P}_{\mathrm{SAT}}$ & \\
\hline & 373.15 & 0.154 & 0.019 & 0.9936 & $0.3-6$ & $P_{S A T}$ & \\
\hline & 423.15 & 0.115 & 0.018 & 0.9890 & $0.3-6$ & $P_{S A T}$ & \\
\hline & 473.15 & 0.075 & 0.037 & 0.9738 & $0.3-6$ & $\mathrm{P}_{\mathrm{SAT}}$ & \\
\hline & 273.15 & 0.230 & 0.024 & 0.9954 & $0.3-6$ & 200 bars & \\
\hline & 298.15 & 0.213 & 0.022 & 0.9956 & $0.3-6$ & 200 bars & \\
\hline & 323.15 & 0.194 & 0.019 & 0.9960 & $0.3-6$ & 200 bars & \\
\hline & 373.15 & 0.157 & 0.019 & 0.9939 & $0.3-6$ & 200 bars & \\
\hline & 423.15 & 0.119 & 0.019 & 0.9898 & $0.3-6$ & 200 bars & \\
\hline & 473.15 & 0.078 & 0.018 & 0.9781 & $0.3-6$ & 200 bars & \\
\hline & 273.15 & 0.235 & 0.024 & 0.9957 & $0.3-6$ & 400 bars & \\
\hline & 298.15 & 0.217 & 0.021 & 0.9959 & $0.3-6$ & 400 bars & \\
\hline & 323.15 & 0.198 & 0.020 & 0.9958 & $0.3-6$ & 400 bars & \\
\hline & 373.15 & 0.162 & 0.019 & 0.9944 & $0.3-6$ & 400 bars & \\
\hline & 423.15 & 0.126 & 0.018 & 0.9909 & $0.3-6$ & 400 bars & \\
\hline & 473.15 & 0.087 & 0.017 & 0.9824 & $0.3-6$ & 400 bars & \\
\hline \multirow{8}{*}{$\varepsilon\left(\mathrm{Ca}^{2+}, \mathrm{Cl}^{-}\right)$} & 273.15 & 0.166 & 0.023 & 0.9922 & $0.3-6$ & $\mathrm{P}_{\mathrm{SAT}}$ & Holmes and Mesmer [27] \\
\hline & 298.15 & 0.161 & 0.021 & 0.9936 & $0.3-6$ & $P_{S A T}$ & Robinson and Stokes [22], Holmes and Mesmer [27] \\
\hline & 323.15 & 0.152 & 0.017 & 0.9945 & $0.3-6$ & $\mathrm{P}_{\mathrm{SAT}}$ & Holmes and Mesmer [27] \\
\hline & 373.15 & 0.124 & 0.013 & 0.9952 & $0.3-6$ & $P_{S A T}$ & \\
\hline & 423.15 & 0.088 & 0.011 & 0.9933 & $0.3-6$ & $\mathrm{P}_{\mathrm{SAT}}$ & \\
\hline & 473.15 & 0.046 & 0.011 & 0.9754 & $0.3-6$ & $P_{S A T}$ & \\
\hline & 273.15 & 0.170 & 0.022 & 0.9928 & $0.3-6$ & 200 bars & Holmes and Mesmer [27] \\
\hline & 298.15 & 0.165 & 0.019 & 0.9942 & $0.3-6$ & 200 bars & \\
\hline
\end{tabular}


Table I: Interaction coefficients involving $\mathrm{Cl}^{-}, \mathrm{OH}^{-}$and $\mathrm{Ac}$ - evaluated by this study at various temperatures (Continued)

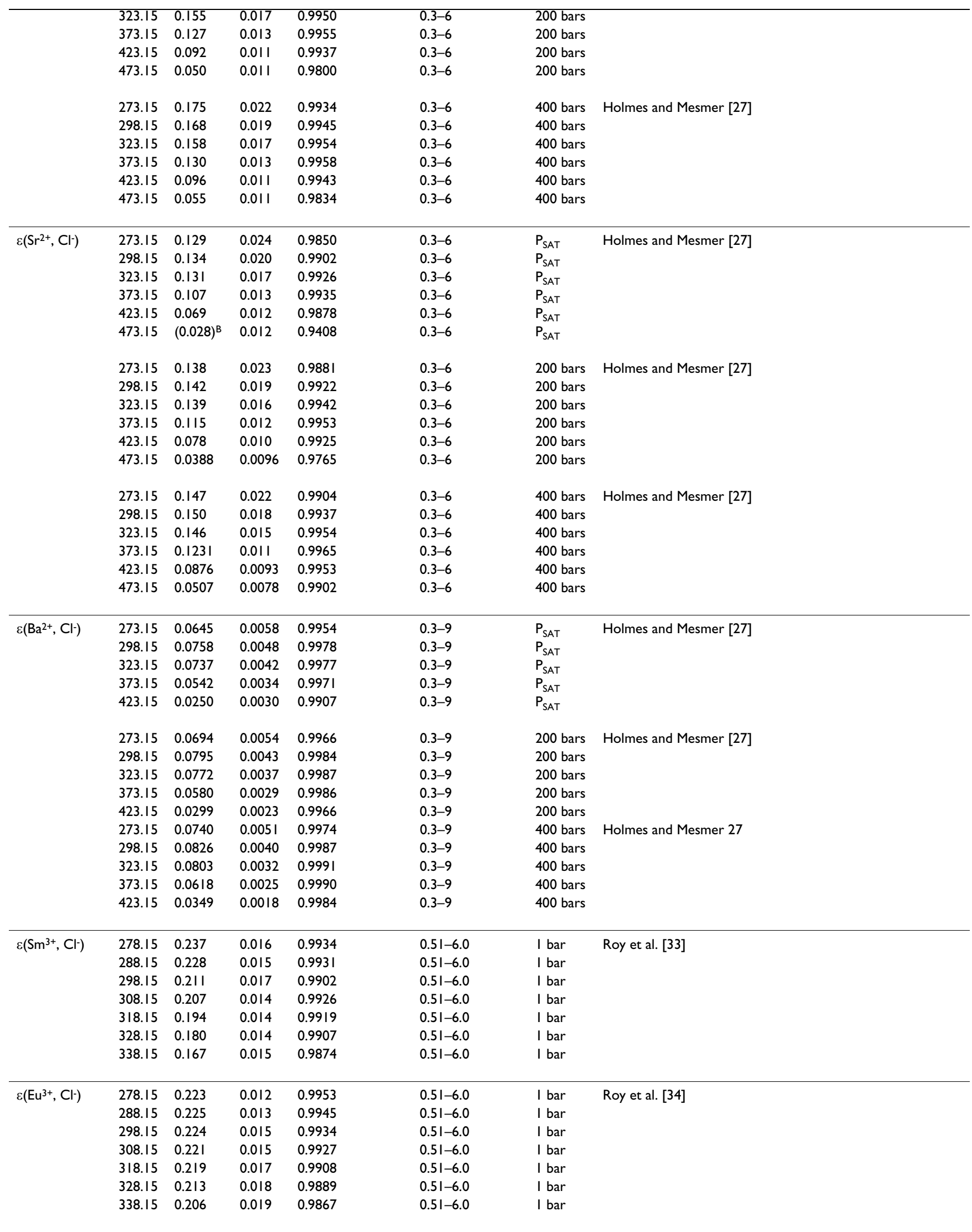


Table I: Interaction coefficients involving $\mathrm{Cl}^{-}, \mathrm{OH}^{-}$and $\mathrm{Ac}$ - evaluated by this study at various temperatures (Continued)

\begin{tabular}{|c|c|c|c|c|c|c|c|}
\hline \multirow[t]{7}{*}{$\varepsilon\left(\mathrm{Gd}^{3+}, \mathrm{Cl}^{-}\right)$} & 278.15 & 0.236 & 0.014 & 0.9944 & $0.5 I-6.0$ & I bar & \multirow[t]{7}{*}{ Roy et al. [28] } \\
\hline & 288.15 & 0.233 & 0.015 & 0.9939 & $0.5 I-6.0$ & I bar & \\
\hline & 298.15 & 0.228 & 0.015 & 0.9932 & $0.5 I-6.0$ & I bar & \\
\hline & 308.15 & 0.222 & 0.015 & 0.9926 & $0.5 I-6.0$ & I bar & \\
\hline & 318.15 & 0.214 & 0.016 & 0.9914 & $0.5 I-6.0$ & I bar & \\
\hline & 328.15 & 0.205 & 0.017 & 0.9896 & $0.5 I-6.0$ & I bar & \\
\hline & 338.15 & 0.195 & 0.017 & 0.9883 & $0.5 I-6.0$ & I bar & \\
\hline \multirow[t]{4}{*}{$\varepsilon\left(\mathrm{GdAc}^{2+}, \mathrm{Cl}^{-}\right)$} & 298.15 & 0.12 & 0.03 & 0.9960 & $0.1-2.0$ & I bar & \multirow[t]{4}{*}{ Ding and Wood [36] } \\
\hline & 313.15 & 0.10 & 0.05 & 0.9710 & $0.1-2.0$ & I bar & \\
\hline & 323.15 & 0.17 & 0.03 & 0.9580 & $0.1-2.0$ & I bar & \\
\hline & 333.15 & 0.13 & 0.03 & 0.8794 & $0.1-2.0$ & I bar & \\
\hline \multirow[t]{6}{*}{$\varepsilon\left(\mathrm{Li}^{+}, \mathrm{OH}^{-}\right)$} & 273.15 & $(-0.03)$ & 0.04 & 0.8826 & 0.1 to 2.0 & $P_{\text {SAT }}$ & Holmes and Mesmer [35] \\
\hline & 298.15 & $(-0.06)$ & 0.03 & 0.8666 & 0.1 to 2.0 & $\mathrm{P}_{\mathrm{SAT}}$ & \multirow[t]{5}{*}{ Robinson and Stokes [22], Holmes and Mesmer [35] } \\
\hline & 323.15 & $(-0.04)$ & 0.03 & 0.9138 & 0.1 to 3.0 & $\mathrm{P}_{\mathrm{SAT}}$ & \\
\hline & 373.15 & -0.0443 & 0.0088 & 0.9435 & 0.1 to 5.0 & $\mathrm{P}_{\mathrm{SAT}}$ & \\
\hline & 423.15 & -0.07 & 0.01 & 0.9571 & 0.1 to 5.0 & $\mathrm{P}_{\mathrm{SAT}}$ & \\
\hline & 473.15 & -0.10 & 0.02 & 0.9563 & 0.1 to 5.0 & $\mathrm{P}_{\mathrm{SAT}}$ & \\
\hline \multirow[t]{6}{*}{$\varepsilon\left(\mathrm{Na}^{+}, \mathrm{OH}^{-}\right)$} & 273.15 & 0.0536 & 0.0096 & 0.9541 & 0.1 to 5.0 & $\mathrm{P}_{\mathrm{SAT}}$ & \multirow[t]{6}{*}{ Holmes and Mesmer [35] } \\
\hline & 298.15 & 0.0573 & 0.0061 & 0.9832 & & $\mathrm{P}_{\mathrm{SAT}}$ & \\
\hline & 323.15 & 0.0546 & 0.0042 & 0.9912 & & $\mathrm{P}_{\mathrm{SAT}}$ & \\
\hline & 373.15 & 0.0392 & 0.0030 & 0.9911 & & $\mathrm{P}_{\mathrm{SAT}}$ & \\
\hline & 423.15 & 0.0189 & 0.0027 & 0.9449 & & $\mathrm{P}_{\mathrm{SAT}}$ & \\
\hline & 473.15 & $(-0.02)$ & 0.03 & 0.9130 & & $\mathrm{P}_{\mathrm{SAT}}$ & \\
\hline \multirow[t]{6}{*}{$\varepsilon\left(\mathrm{K}^{+}, \mathrm{OH}^{-}\right)$} & 273.15 & 0.1017 & 0.0055 & 0.9956 & 0.1 to 5.0 & $P_{S A T}$ & \multirow[t]{6}{*}{ Holmes and Mesmer [35] } \\
\hline & 298.15 & 0.0994 & 0.0039 & 0.9978 & & $\mathrm{P}_{\mathrm{SAT}}$ & \\
\hline & 323.15 & 0.0859 & 0.0029 & 0.9983 & & $\mathrm{P}_{\mathrm{SAT}}$ & \\
\hline & 373.15 & 0.0550 & 0.0029 & 0.9959 & & $\mathrm{P}_{\mathrm{SAT}}$ & \\
\hline & 423.15 & 0.0331 & 0.0039 & 0.9806 & & $\mathrm{P}_{\mathrm{SAT}}$ & \\
\hline & 473.15 & $(0.0189)$ & 0.0065 & 0.9115 & & $\mathrm{P}_{\mathrm{SAT}}$ & \\
\hline \multirow[t]{6}{*}{$\varepsilon\left(\mathrm{Cs}^{+}, \mathrm{OH}^{-}\right)$} & 273.15 & 0.1064 & 0.0065 & 0.9944 & 0.1 to 5.0 & $\mathrm{P}_{\mathrm{SAT}}$ & \multirow{6}{*}{ Holmes and Mesmer [35] } \\
\hline & 298.15 & 0.1061 & 0.0049 & 0.9968 & & $\mathrm{P}_{\mathrm{SAT}}$ & \\
\hline & 323.15 & 0.1015 & 0.0039 & 0.9978 & & $\mathrm{P}_{\mathrm{SAT}}$ & \\
\hline & 373.15 & 0.0839 & 0.0039 & 0.9968 & & $\mathrm{P}_{\text {SAT }}$ & \\
\hline & 423.15 & 0.0615 & 0.0054 & 0.9885 & & $\mathrm{P}_{\text {SAT }}$ & \\
\hline & 473.15 & 0.0435 & 0.0077 & 0.9745 & & $\mathrm{P}_{\mathrm{SAT}}$ & \\
\hline$\varepsilon\left(\mathrm{Sr}^{2+}, \mathrm{OH}^{-}\right)$ & 298.15 & -0.11 & 0.02 & 0.9138 & 0.2 to 4.0 & I bar & Johnston and Grove [40] \\
\hline$\varepsilon\left(\mathrm{Ba}^{2+}, \mathrm{OH}^{-}\right)$ & 298.15 & -0.10 & 0.01 & 0.8881 & 0.1 to 4.9 & I bar & Johnston and Grove [40] \\
\hline \multirow[t]{10}{*}{$\varepsilon\left(\mathrm{Na}^{+}, \mathrm{Ac}^{-}\right)$} & 273.15 & 0.0755 & 0.0027 & 0.9999 & 0.1 to 2.0 & I bar & Partanen and Covington [39] \\
\hline & 283.15 & 0.0593 & 0.0030 & 0.9999 & 0.1 to 2.0 & I bar & Partanen and Covington [39] \\
\hline & 298.15 & 0.0399 & 0.0060 & 0.9952 & 0.1 to 5.0 & I bar & $\begin{array}{l}\text { Kiss and Urmánczy [37]; Mesmer et al. [38]; Ding and Wood } \\
\text { [36]; Partanen and Covington [39] }\end{array}$ \\
\hline & 313.15 & 0.03 & 0.02 & 0.9816 & 0.1 to 2.0 & I bar & Ding and Wood (2002) 36; Partanen and Covington [39] \\
\hline & 323.15 & 0.0304 & 0.0077 & 0.9917 & 0.1 to 5.0 & I bar & $\begin{array}{l}\text { Mesmer et al. [38]; Ding and Wood [36]; Partanen and } \\
\text { Covington [39] }\end{array}$ \\
\hline & 348.15 & 0.0275 & 0.0068 & 0.9980 & 0.1 to 5.0 & I bar & Mesmer et al. [38] \\
\hline & 373.15 & 0.0155 & 0.0059 & 0.9977 & 0.1 to 5.0 & $\mathrm{P}_{\mathrm{SAT}}$ & Mesmer et al. [38] \\
\hline & 398.15 & 0.003 & 0.006 & 0.9962 & 0.1 to 5.0 & $\mathrm{P}_{\mathrm{SAT}}$ & Mesmer et al. [38] \\
\hline & 423.15 & -0.007 & 0.006 & 0.9876 & 0.1 to 5.0 & $\mathrm{P}_{\mathrm{SAT}}$ & Mesmer et al. [38] \\
\hline & 448.15 & -0.0157 & 0.0089 & 0.9643 & 0.1 to 5.0 & $\mathrm{P}_{\mathrm{SAT}}$ & Mesmer et al. [38] \\
\hline$\varepsilon\left(\mathrm{Ca}^{2+}, \mathrm{Ac}^{-}\right)$ & 298.15 & -0.04 & 0.02 & 0.9619 & 0.2 to 4.9 & I bar & Johnston and Grove [40] \\
\hline
\end{tabular}

\footnotetext{
${ }^{A} P_{S A T}$ : Saturated vapor pressure; ${ }^{B}$ Values in parentheses are considered to be less precise because of lower linearity of fitting or larger $2 \sigma$.
} 
Table 2: $\Delta \varepsilon$ (Eq. 4) evaluated from formation quotients of $\mathbf{G d A c}^{2+}$ of Ding and Wood [36]

\begin{tabular}{llll}
\hline Temperature, $\mathrm{K}$ & $\Delta \varepsilon$ (Eq. 4) & $2 \sigma$ & $\begin{array}{l}\text { Linearity of Fitting (Square of } \\
\left.\text { Linear Correlation Coefficient, } R^{2}\right)\end{array}$ \\
\hline 298.15 & 0.228 & 0.022 & 0.9960 \\
313.15 & 0.158 & 0.036 & 0.9710 \\
323.15 & 0.074 & 0.016 & 0.9580 \\
333.15 & $(0.04)$ & 0.02 & 0.8794 \\
\hline
\end{tabular}

concentrations of $\mathrm{EuCl}_{3}$ from $0.1 \mathrm{~m}$ to $1.0 \mathrm{~m}$ up to $65^{\circ} \mathrm{C}$ at 1 bar are reproduced by using the temperature dependence relations of the Pitzer parameters from Roy et al. [34]. Then, the interaction coefficients of $\varepsilon\left(\mathrm{Eu}^{3+}, \mathrm{Cl}^{-}\right)$up to $65^{\circ} \mathrm{C}$ are evaluated from the mean activity coefficients of $\mathrm{EuCl}_{3}$ solutions.

Holmes and Mesmer [35] presented mean activity coefficients for $\mathrm{LiOH}, \mathrm{NaOH}, \mathrm{KOH}$, and $\mathrm{CsOH}$ solutions at ionic strengths up to $5.0 \mathrm{~m}$ based on isopiestic studies at $\mathrm{P}_{\mathrm{SAT}}$. Accordingly, interaction coefficients of $\varepsilon\left(\mathrm{Li}^{+}, \mathrm{OH}^{-}\right)$, $\varepsilon\left(\mathrm{Na}^{+}, \mathrm{OH}^{-}\right), \varepsilon\left(\mathrm{K}^{+}, \mathrm{OH}^{-}\right)$, and $\varepsilon\left(\mathrm{Cs}^{+}, \mathrm{OH}^{-}\right)$are evaluated from the mean activity coefficients of Holmes and Mesmer [35].

\section{Interaction coefficients derived from equilibrium quotients with ionic strength dependence}

Ding and Wood [36] determined the stability quotients of acetate complexes of $\mathrm{La}^{3+}, \mathrm{Nd}^{3+}, \mathrm{Gd}^{3+}$ and $\mathrm{Yb}^{3+}$ at $25-$ $70^{\circ} \mathrm{C}$ and 1 bar in $\mathrm{NaCl}$ media by potentiometric titration. The stability quotient can be expressed for the following general reaction:

$\mathrm{Ln}^{3+}+\mathrm{Ac}^{-}=\mathrm{LnAc}^{2+}$

As the interaction coefficient of $\varepsilon\left(\mathrm{Gd}^{3+}, \mathrm{Cl}^{-}\right)$is evaluated up to $65^{\circ} \mathrm{C}$ in the above section, the interaction coefficient of $\varepsilon\left(\mathrm{GdAc}^{2+}, \mathrm{Cl}^{-}\right)$can be evaluated from their stability quotients for $\mathrm{GdAc}^{2+}$ up to $60^{\circ} \mathrm{C}$. The interaction coefficient of $\varepsilon\left(\mathrm{GdAc}^{2+}, \mathrm{Cl}^{-}\right)$at $70^{\circ} \mathrm{C}$ is not evaluated from their stability quotients because of poor linearity with ionic strength at that temperature.

For Reaction (4) regarding the formation of $\mathrm{GdAc}^{2+}$ in $\mathrm{NaCl}$ media, we have:

$\log \mathrm{K}_{(4)}^{\circ}=\log \mathrm{Q}_{(4)}+6 \mathrm{D}+\Delta \varepsilon($ Eq. 4$) \mathrm{I}_{\mathrm{m}}$

Rearranging, we have

$\log \mathrm{Q}_{(4)}+6 \mathrm{D}=\log \mathrm{K}_{(4)}^{\circ}-\Delta \varepsilon($ Eq. 4$) \mathrm{I}_{\mathrm{m}}$

where $\log \mathrm{K}^{\circ}{ }_{(4)}$ is the stability constant at infinite dilution, and $\log \mathrm{Q}_{(4)}$ is the stability quotient at certain ionic strength, $\mathrm{I}_{\mathrm{m}}$ is the ionic strength of $\mathrm{NaCl}$ solutions on the molal scale, and $\Delta \varepsilon$ (Eq. 4) is given by the following expression according to the stoichiometry of Eq. (4):

$\Delta \varepsilon\left(\right.$ Eq. 4) $\mathrm{I}_{\mathrm{m}}=\varepsilon\left(\mathrm{GdAc}^{2+}, \mathrm{Cl}^{-}\right) \mathrm{I}_{\mathrm{m}}-\varepsilon\left(\mathrm{Gd}^{3+}, \mathrm{Cl}^{-}\right) \mathrm{I}_{\mathrm{m}}-\varepsilon\left(\mathrm{Na}^{+}\right.$, Ac-) $\mathrm{I}_{\mathrm{m}} \quad$ (7)

According to Eq. (6), $\Delta \varepsilon$ (Eq. 4) can be obtained by plotting $\log \mathrm{Q}_{(4)}+6 \mathrm{D}$ versus $\mathrm{I}_{\mathrm{m}}$ and $\Delta \varepsilon$ (Eq. 4 ) obtained in this manner are tabulated in Table 2. However, in order to derive $\varepsilon\left(\mathrm{GdAc}^{2+}, \mathrm{Cl}^{-}\right)$from $\Delta \varepsilon$ (Eq. 4) according to Eq. (7), $\varepsilon\left(\mathrm{Na}^{+}, \mathrm{Ac}^{-}\right)$must be known.

To achieve this, the interaction coefficients of $\varepsilon\left(\mathrm{Na}^{+}, \mathrm{Ac}-\right)$ at temperatures up to $175^{\circ} \mathrm{C}$ are evaluated from dissociation quotients of $\mathrm{HAc}$ in $\mathrm{NaCl}$ media assuming unity for the activity coefficient of HAc:

$\mathrm{HAC}=\mathrm{H}^{+}+\mathrm{Ac}^{-}(8)$

Similar to Eq. (6), we have

$\log \mathrm{Q}_{(8)}-2 \mathrm{D}=\log \mathrm{K}_{(8)}^{\circ}-\Delta \varepsilon\left(\right.$ Eq. 8) $\mathrm{I}_{\mathrm{m}}$

where $\Delta \varepsilon($ Eq. 8$)$ is given by

$\Delta \varepsilon($ Eq. 8$)=\left[\varepsilon\left(\mathrm{H}^{+}, \mathrm{Cl}^{-}\right)+\varepsilon\left(\mathrm{Na}^{+}, \mathrm{Ac}^{-}\right)\right]$

Therefore, when $\Delta \varepsilon$ (Eq. 8) are evaluated according to Eq. (9), $\varepsilon\left(\mathrm{Na}^{+}, \mathrm{Ac}-\right)$ then can be derived in combination with $\varepsilon\left(\mathrm{H}^{+}, \mathrm{Cl}^{-}\right)$evaluated in this study.

In estimation of $\Delta \varepsilon$ (Eq. 8), dissociation quotients of HAc in $\mathrm{NaCl}$ media determined by Kiss and Urmáncy [37], Mesmer et al. [38], Ding and Wood [36] and Partanen and Covington [39] are utilized, and $\Delta \varepsilon$ (Eq. 8) are tabulated in Table 3

Johnston and Grove [40] studied the solubility of portlandite in various media at $25^{\circ} \mathrm{C}$. According to the solubility product quotients of portlandite in $\mathrm{NaAc}, \mathrm{SrCl}_{2}$ and $\mathrm{BaCl}_{2}$ regarding the following reaction:

$\mathrm{Ca}(\mathrm{OH})_{2}(\mathrm{~s})=\mathrm{Ca}^{2+}+2 \mathrm{OH}^{-}$

the interaction coefficients of $\varepsilon\left(\mathrm{Ca}^{2+}, \mathrm{Ac}^{-}\right), \varepsilon\left(\mathrm{Sr}^{2+}, \mathrm{OH}^{-}\right)$, and $\varepsilon\left(\mathrm{Ba}^{2+}, \mathrm{OH}^{-}\right)$at $25^{\circ} \mathrm{C}$ are also estimated from the experimental data of Johnston and Grove [40]. These interaction coefficients are derived from $\Delta \varepsilon$ (Eq. 11) listed in Table 4 in conjunction with $\varepsilon\left(\mathrm{Na}^{+}, \mathrm{OH}^{-}\right)$or $\varepsilon\left(\mathrm{Ca}^{2+}, \mathrm{Cl}^{-}\right.$ ) at $25^{\circ} \mathrm{C}$ estimated in this study. These interaction coefficients, $\varepsilon\left(\mathrm{Ca}^{2+}, \mathrm{Ac}^{-}\right), \varepsilon\left(\mathrm{Sr}^{2+}, \mathrm{OH}^{-}\right)$, and $\varepsilon\left(\mathrm{Ba}^{2+}, \mathrm{OH}^{-}\right)$, are not covered in Ciavatta $[12,13]$, and therefore are not compiled in Grenthe et al. [14] nor in Guillaumont et al. [15]. 
Table 3: $\Delta \varepsilon$ (Eq. 8) evaluated from dissociation quotients of acetic acid (log $\mathbf{Q}$ ) in $\mathrm{NaCl}$ solutions

\begin{tabular}{llllll}
\hline Temp., K & $\Delta \varepsilon$ (Eq. 8) & I range, $\mathrm{m}$ & $2 \sigma$ & $\begin{array}{l}\text { Linearity of Fitting } \\
\text { (Square of Linear } \\
\text { Correlation } \\
\left.\text { Coefficient, } \mathrm{R}^{2}\right)\end{array}$ & Data Sources for Evaluation \\
\hline 273.15 & 0.2047 & $0.1-2.0$ & 0.0015 & 0.9999 & Partanen and Covington [39] \\
283.15 & 0.1903 & $0.1-2.0$ & 0.0020 & 0.9999 & $\begin{array}{l}\text { Partanen and Covington [39] } \\
298.15\end{array}$ \\
& 0.1704 & $0.1-5.0$ & 0.0056 & 0.9952 & Kiss and Urmánczy [37]; Mesmer et al. [38]; Ding and Wood [36]; Partanen and \\
313.15 & 0.148 & $0.1-2.0$ & 0.028 & 0.9816 & Covington [39] \\
323.15 & 0.1405 & $0.1-5.0$ & 0.0074 & 0.9917 & Ding and Wood [36]; Partanen and Covington [39] \\
348.15 & 0.1232 & $0.1-5.0$ & 0.0064 & 0.9980 & Mesmer et al. [38]; Ding and Wood [36]; Partanen and Covington [39] \\
373.15 & 0.0995 & $0.1-5.0$ & 0.0055 & 0.9977 & Mesmer et al. [38] \\
398.15 & 0.0753 & $0.1-5.0$ & 0.0053 & 0.9962 & Mesmer et al. [38] \\
423.15 & 0.0506 & $0.1-5.0$ & 0.0065 & 0.9876 & Mesmer et al. [38] \\
448.15 & 0.0283 & $0.1-5.0$ & 0.0085 & 0.9643 & Mesmer et al. [38] \\
\hline
\end{tabular}

Seward [41] determined the solubilities of $\mathrm{AgCl}$ (s) (cerargyrite) in $\mathrm{NaCl}$ solutions of up to $3.0 \mathrm{~m}$. For the solubility product constant, $\mathrm{K}_{\mathrm{s} 0}^{\circ}$, the reaction can be expressed as

$\mathrm{AgCl}(\mathrm{s})=\mathrm{Ag}^{+}+\mathrm{Cl}^{-} \quad(12)$

In the study of Seward [41], equilibrium constants such as $\mathrm{K}^{\circ}{ }_{\mathrm{s} 0}$ were extrapolated to infinite dilution by using the $\mathrm{B}$ dot equation [9], and equilibrium quotients (conditional equilibrium constants) were not presented. In this study, respective equilibrium quotients are recalculated according to the $\mathrm{B}$ dot equation. For instance, $\mathrm{Q}_{\mathrm{s} 0}$ are recalculated as

$\log \mathrm{Q}_{\mathrm{s} 0}=\log \mathrm{m}_{\mathrm{Ag}^{+}}+\log \mathrm{m}_{\mathrm{Cl}^{-}}=\log \mathrm{K}_{\mathrm{s} 0}^{\mathrm{O}}-\log \gamma_{\mathrm{Ag}^{+}}-\log \gamma_{\mathrm{Cl}^{-}}$

In the work of Seward [41], $\log \gamma_{\mathrm{Ag}^{+}}$was calculated by using the B dot equation. $\log \gamma_{\mathrm{Cl}^{-}}$was calculated from the stoichiometric mean activity coefficient of $\mathrm{NaCl}$ from Liu and Lindsay [42]:

$\gamma_{\mathrm{Cl}^{-}}=\frac{\gamma_{ \pm, N a C l}}{\alpha}$

where $\alpha$ is the degree of dissociation of the $\mathrm{NaCl}^{\circ}$ ion pair and is defined as: $\alpha=1-\gamma_{ \pm, \mathrm{NaCl}}^{2}\left[\mathrm{Cl}^{-}\right] /\left(\mathrm{K}_{\mathrm{d}} \gamma_{\mathrm{NaCl}^{\circ}}\right)$

In the work of Seward [41], unity is assumed for $\gamma_{\mathrm{NaClo}^{\prime}}$ and a temperature dependence expression was given for dissociation constants of $\mathrm{NaCl}^{\circ}\left(\mathrm{K}_{\mathrm{d}}\right)$.

Accordingly, for Reaction (12) in $\mathrm{NaCl}$ media, we have:

$\log \mathrm{Q}_{\mathrm{s} 0(12)}-2 \mathrm{D}=\log \mathrm{K}_{\mathrm{s} 0(12)}^{\circ}-\Delta \varepsilon\left(\right.$ Eq. 12) $\mathrm{I}_{\mathrm{m}}$

where $\Delta \varepsilon$ (Eq. 12) is given by

$\Delta \varepsilon\left(\right.$ Eq. 12) $=\left[\varepsilon\left(\mathrm{Ag}^{+}, \mathrm{Cl}^{-}\right)+\varepsilon\left(\mathrm{Na}^{+}, \mathrm{Cl}^{-}\right)\right]$

The estimated $\Delta \varepsilon$ (Eq. 12) are listed in Table 5. Therefore, based upon $\varepsilon\left(\mathrm{Na}^{+}, \mathrm{Cl}\right)$ evaluated before, $\varepsilon\left(\mathrm{Ag}^{+}, \mathrm{Cl}-\right)$ can be derived from $\Delta \varepsilon$ (Eq. 12), and they are listed in Table 1 .

Similarly, for the cumulative equilibrium quotient, $\mathrm{Q}_{2}$, we have,

$\mathrm{Ag}^{+}+2 \mathrm{Cl}^{-}=\mathrm{AgCl}_{2}^{-}(18)$

Accordingly, we have the following expression:

$\log \mathrm{Q}_{2(18)}+2 \mathrm{D}=\log \beta^{\circ}{ }_{2(18)}-\Delta \varepsilon \mathrm{I}_{\mathrm{m}}$

Table 4: $\Delta \varepsilon$ (Eq. I I) estimated from solubility product quotients of portlandite in various media at $25^{\circ} \mathrm{C}$

\begin{tabular}{lllll}
\hline Medium & $\Delta \varepsilon($ Eq. II) $( \pm 2 \sigma)$ & lonic Strength Range, $\mathrm{m}$ & $\begin{array}{l}\text { Linearity of Fitting (Square } \\
\text { of Linear Correlation } \\
\left.\text { Coefficient, } \mathrm{R}^{2}\right)\end{array}$ & $\begin{array}{l}\text { Experimental Data Source } \\
\text { for Estimation }\end{array}$ \\
\hline $\mathrm{NaAc}$ & $0.07 \pm 0.02$ & $0.2-4.9$ & 0.9619 & Johnston and Grove [40] \\
$\mathrm{SrCl}_{2}$ & $-0.06 \pm 0.02$ & $0.2-4.0$ & 0.9138 & \\
$\mathrm{BaCl}_{2}$ & $-0.035 \pm 0.008$ & $0.1-4.9$ & $0.888 \mathrm{I}$ &
\end{tabular}


Table 5: $\Delta \varepsilon$ (Eq. 12) evaluated from solubility quotients $\left(\log \mathbf{Q}_{\mathrm{s}}\right)$ of $\mathbf{A g C l}(\mathrm{s})$ in $\mathrm{NaCl}$ solutions

\begin{tabular}{llllll}
\hline Temp., $\mathrm{K}$ & $\Delta \varepsilon(\mathrm{Eq} .12)$ & I range, $\mathrm{m}$ & $2 \sigma$ & $\begin{array}{l}\text { Linearity of Fitting (Square of } \\
\left.\text { Linear Correlation Coefficient, } \mathrm{R}^{2}\right)\end{array}$ & Data Sources for Evaluation \\
\hline 373.15 & 0.127 & $0.5-3.0$ & 0.014 & 0.9842 & Seward [4I] \\
423.15 & 0.144 & $0.5-3.0$ & 0.019 & 0.9825 & \\
470.15 & 0.152 & $0.5-3.0$ & 0.019 & 0.9840 & \\
\hline
\end{tabular}

where $\Delta \varepsilon$ (Eq. 18) is defined by

$\Delta \varepsilon($ Eq. 18$)=\left[\varepsilon\left(\mathrm{Na}^{+}, \mathrm{AgCl}_{2}{ }^{-}\right)-\varepsilon\left(\mathrm{Ag}^{+}, \mathrm{Cl}^{-}\right)-2 \varepsilon\left(\mathrm{Na}^{+}, \mathrm{Cl}^{-}\right)\right]$ (20)

The evaluated $\Delta \varepsilon$ (Eq. 18) are listed in Table 6. According to $\varepsilon\left(\mathrm{Na}^{+}, \mathrm{Cl}\right)$ and $\varepsilon\left(\mathrm{Ag}^{+}, \mathrm{Cl}^{-}\right)$evaluated above, $\varepsilon\left(\mathrm{Na}^{+}\right.$, $\mathrm{AgCl}_{2}^{-}$) can be derived from $\Delta \varepsilon$ (Eq. 18), and they are tabulated in Table 1.

Based upon the interaction coefficients estimated at various temperatures, their respective temperature dependence expressions are presented in Table 7. While two-term polynomial fittings can almost exactly reproduce interaction coefficients at various temperatures, linear fittings for some interaction coefficients can also reproduce interaction coefficients at various temperatures within uncertainty of $2 \sigma$ as exemplified by the case for $\varepsilon\left(\mathrm{Ca}^{2+}, \mathrm{Cl}^{-}\right)$at various temperatures (Figure 2). Although both linear and two-term polynomial expressions are given for some interaction coefficients, it is recommended to use twoterm polynomial expressions for interpolations. Linear relations for some interaction coefficients might be used for extrapolations over a limited range of temperatures beyond the temperatures at which they are evaluated (say, over a limited range of $\left.\sim 25^{\circ} \mathrm{C}\right)$. For instance, as $\varepsilon\left(\mathrm{Na}^{+}\right.$, $\mathrm{AgCl}_{2}^{-}$) is evaluated at $100^{\circ} \mathrm{C}-197^{\circ} \mathrm{C}$, it might be possible to extrapolate the interaction coefficient to $75^{\circ} \mathrm{C}$ by using its linear expression.

\section{Model verification and applications}

As the intent of this study is to provide a framework to treat medium dependence of equilibrium constants at elevated temperatures by using the SIT model, consequently, the model verification is focused on testing whether interaction coefficients recommended by this study can pro- vide reasonable accuracy in reproduction of medium effects on equilibrium constants. To achieve this goal, experimentally determined mean activity coefficients and equilibrium quotients at various ionic strengths are compared with respective values predicted by using the interaction coefficients estimated by this study. The strategy in the model verification is to use experimental data from independent studies, which are not considered in estimation of interaction coefficients.

\section{Mean activity coefficient data}

In comparison of predicted mean activity coefficients with experimental values, differences are given in sigma values $(\sigma)$. Similarly to Christov and Moller [43], sigma is defined as follows for mean activity coefficients:

$\sigma=\sqrt{\sum_{i=1}^{n} \frac{\left(x(i)_{\exp }-x(i)_{\text {pred }}\right)^{2}}{n}}$

where $x(\mathrm{i})_{\exp }$ is the value of the $i$ th experimental data point of the quantity $x, x(\mathrm{i})_{\text {pred }}$ is the corresponding predicted value of the quantity $x$, and $n$ is the number of points in the data set.

In Table 8, the interaction coefficients estimated in this study are tested against independent experimental data on mean activity coefficients. The bulk of experimental mean activity coefficient data prior to 1989 are those selected by Lobo [44] and Lobo and Quaresma [45]. The $\sigma$ values listed in Table 8 indicate the expected accuracy when these interaction coefficients are used. For some interaction coefficients, especially those involving complexes, because experimental data on mean activity coefficient are lacking, they are tested against equilibrium quotients (see below).

Table 6: $\Delta \varepsilon$ (Eq. 18) evaluated from the cumulative equilibrium quotients of $\mathbf{A g C l}\left(\log \mathbf{Q}_{2}\right)$ in $\mathrm{NaCl}$

\begin{tabular}{llllll}
\hline Temp., $\mathrm{K}$ & $\Delta \varepsilon$ (Eq. I8) & I range, $\mathrm{m}$ & $2 \sigma$ & $\begin{array}{l}\text { Linearity of Fitting (Square of Linear } \\
\left.\text { Correlation Coefficient, } \mathrm{R}^{2}\right)\end{array}$ & $\begin{array}{l}\text { Data Sources for } \\
\text { Evaluation }\end{array}$ \\
\hline 373.15 & -0.194 & $0.5-3.0$ & 0.023 & 0.9821 & Seward [4I] \\
423.15 & -0.227 & $0.5-3.0$ & 0.032 & 0.9807 & \\
470.15 & -0.243 & $0.5-3.0$ & 0.032 & 0.9832 & \\
\hline
\end{tabular}


Table 7: Temperature dependence expressions for interaction coefficients involving $\mathrm{Cl}^{-}, \mathrm{OH}^{-}$and $\mathrm{Ac}^{-}$derived from this study

\begin{tabular}{|c|c|c|c|c|}
\hline $\begin{array}{l}\text { Interaction } \\
\text { Coefficients }\end{array}$ & Temperature Dependence Expressions, $\mathrm{T}$ in $\mathrm{K}$ & Average $2 \sigma$ & $\begin{array}{l}\text { lonic Strength } \\
\text { Range, } \mathrm{m}\end{array}$ & Temperature Range and Pressure \\
\hline \multirow[t]{2}{*}{$\varepsilon\left(\mathrm{H}^{+}, \mathrm{Cl}^{-}\right)$} & Linear: $\varepsilon=2.7890 \times 10^{-1}-5.2237 \times 10^{-4} \mathrm{~T}\left(\mathrm{R}^{2}=0.9950\right)$ & 0.0019 & $0.1-6.0$ & $298.15-473.15 \mathrm{~K}$ at $\mathrm{P}_{\mathrm{SAT}}$ \\
\hline & Polynomial: $\varepsilon=3.8988 \times 10^{-1}-1.0783 \times 10^{-3} \mathrm{~T}-6.9000 \times 10^{-7} \mathrm{~T}^{2}\left(\mathrm{R}^{2}=0.9968\right)$ & & & \\
\hline \multirow[t]{2}{*}{$\varepsilon\left(\mathrm{H}^{+}, \mathrm{Cl}^{-}\right)$} & Linear: $\varepsilon=2.5259 \times 10^{-1}-4.4384 \times 10^{-4} \mathrm{~T}\left(\mathrm{R}^{2}=0.9985\right)$ & 0.0010 & $0.1-2.0$ & $273.15-473.15 \mathrm{~K}$ at 400 bars \\
\hline & Polynomial: $\varepsilon=2.1154 \times 10^{-1}-2.0587 \times 10^{-4} \mathrm{~T}-3.3783 \times 10^{-7} \mathrm{~T}^{2}\left(\mathrm{R}^{2}=0.9998\right)$ & & & \\
\hline$\varepsilon\left(\mathrm{Na}^{+}, \mathrm{Cl}\right)$ & $\varepsilon=-4.1341 \times 10^{-2}+5.8237 \times 10^{-4} \mathrm{~T}-9.5405 \times 10^{-7} \mathrm{~T}^{2}\left(\mathrm{R}^{2}=0.9974\right)$ & 0.0007 & $0.5-6.0$ & $298.15-473.15 \mathrm{~K}$ at $\mathrm{P}_{\mathrm{SAT}}$ \\
\hline \multirow[t]{2}{*}{$\varepsilon\left(\mathrm{Na}^{+}, \mathrm{AgCl}_{2}^{-}\right)$} & Linear: $\varepsilon=1.7132 \times 10^{-1}-5.1636 \times 10^{-4} \mathrm{~T}\left(\mathrm{R}^{2}=0.9906\right)$ & 0.03 & $0.5-3.0$ & $373.15-473.15 \mathrm{~K}$ at $\mathrm{P}_{\mathrm{SAT}}$ \\
\hline & Polynomial: $\varepsilon=4.8789 \times 10^{-1}-2.0323 \times 10^{-3} \mathrm{~T}-1.7986 \times 10^{-6} \mathrm{~T}^{2}\left(\mathrm{R}^{2}=1.0000\right)$ & & & \\
\hline$\varepsilon\left(\mathrm{Ag}^{+}, \mathrm{Cl}^{-}\right)$ & $\varepsilon=0.11$ & 0.02 & $0.5-3.0$ & $373.15-473.15 \mathrm{~K}$ at $\mathrm{P}_{\mathrm{SAT}}$ \\
\hline \multirow[t]{2}{*}{$\varepsilon\left(\mathrm{Mg}^{2+}, \mathrm{Cl}^{-}\right)$} & Linear: $\varepsilon=4.4121 \times 10^{-1}-7.7283 \times 10^{-4} \mathrm{~T}\left(\mathrm{R}^{2}=0.9995\right)$ & 0.030 & $0.3-6.0$ & $273.15-473.15 \mathrm{~K}$ at $\mathrm{P}_{\mathrm{SAT}}$ \\
\hline & Polynomial: $\varepsilon=4.4442 \times 10^{-1}-7.9072 \times 10^{-4} \mathrm{~T}+2.4016 \times 10^{-8} \mathrm{~T}^{2}\left(\mathrm{R}^{2}=0.9995\right)$ & & & \\
\hline \multirow[t]{2}{*}{$\varepsilon\left(\mathrm{Mg}^{2+}, \mathrm{Cl}^{-}\right)$} & Linear: $\varepsilon=4.3772 \times 10^{-1}-7.5556 \times 10^{-4} \mathrm{~T}\left(\mathrm{R}^{2}=0.9994\right)$ & 0.031 & $0.3-6.0$ & $273.15-473.15 \mathrm{~K}$ at 200 bars \\
\hline & Polynomial: $\varepsilon=3.9380 \times 10^{-1}-5.1076 \times 10^{-4} \mathrm{~T}-3.2860 \times 10^{-7} \mathrm{~T}^{2}\left(\mathrm{R}^{2}=0.9999\right)$ & & & \\
\hline \multirow[t]{2}{*}{$\varepsilon\left(\mathrm{Mg}^{2+}, \mathrm{Cl}^{-}\right)$} & Linear: $\varepsilon=4.3685 \times 10^{-1}-7.3773 \times 10^{-4} \mathrm{~T}\left(\mathrm{R}^{2}=0.9999\right)$ & 0.029 & $0.3-6.0$ & $273.15-473.15 \mathrm{~K}$ at 400 bars \\
\hline & Polynomial: $\varepsilon=4.2439 \times 10^{-1}-6.6827 \times 10^{-4} \mathrm{~T}-9.3235 \times 10^{-8} \mathrm{~T}^{2}\left(\mathrm{R}^{2}=0.9999\right)$ & & & \\
\hline \multirow[t]{2}{*}{$\varepsilon\left(\mathrm{Ca}^{2+}, \mathrm{Cl}^{-}\right)$} & Linear: $\varepsilon=3.6437 \times 10^{-1}-6.6172 \times 10^{-4} \mathrm{~T}\left(\mathrm{R}^{2}=0.9857\right)$ & 0.030 & $0.3-6.0$ & $298.15-473.15 \mathrm{~K}$ at $\mathrm{P}_{\mathrm{SAT}}$ \\
\hline & Polynomial: $\varepsilon=1.2880 \times 10^{-1}+5.9815 \times 10^{-4} \mathrm{~T}-1.6373 \times 10^{-6} \mathrm{~T}^{2}\left(\mathrm{R}^{2}=0.9999\right)$ & & & \\
\hline \multirow[t]{2}{*}{$\varepsilon\left(\mathrm{Ca}^{2+}, \mathrm{Cl}^{-}\right)$} & Linear: $\varepsilon=3.6445 \times 10^{-1}-6.5439 \times 10^{-4} \mathrm{~T}\left(\mathrm{R}^{2}=0.9919\right)$ & 0.020 & $0.3-6.0$ & $298.15-473.15 \mathrm{~K}$ at 200 bars \\
\hline & Polynomial: $\varepsilon=1.9626 \times 10^{-1}+2.4509 \times 10^{-4} \mathrm{~T}-1.1690 \times 10^{-6} \mathrm{~T}^{2}\left(\mathrm{R}^{2}=0.9993\right)$ & & & \\
\hline \multirow[t]{2}{*}{$\varepsilon\left(\mathrm{Ca}^{2+}, \mathrm{Cl}^{-}\right)$} & Linear: $\varepsilon=3.6440 \times 10^{-1}-6.4277 \times 10^{-4} \mathrm{~T}\left(\mathrm{R}^{2}=0.9891\right)$ & 0.020 & $0.3-6.0$ & $298.15-473.15 \mathrm{~K}$ at 400 bars \\
\hline & Polynomial: $\varepsilon=1.645 \mathrm{I} \times 10^{-1}+4.2626 \times 10^{-4} \mathrm{~T}-1.3893 \times 10^{-6} \mathrm{~T}^{2}\left(\mathrm{R}^{2}=0.9999\right)$ & & & \\
\hline \multirow[t]{2}{*}{$\varepsilon\left(\mathrm{Sr}^{2+}, \mathrm{Cl}^{-}\right)$} & Linear: $\varepsilon=3.2535 \times 10^{-1}-6.1153 \times 10^{-4} \mathrm{~T}\left(\mathrm{R}^{2}=0.9716\right)$ & 0.018 & $0.3-6.0$ & $298.15-473.15 \mathrm{~K}$ at $\mathrm{P}_{\mathrm{SAT}}$ \\
\hline & Polynomial: $\varepsilon=3.1779 \times 10^{-2}+9.5849 \times 10^{-4} \mathrm{~T}-2.0404 \times 10^{-6} \mathrm{~T}^{2}\left(\mathrm{R}^{2}=0.9970\right)$ & & & \\
\hline \multirow[t]{2}{*}{$\varepsilon\left(\mathrm{Sr}^{2+}, \mathrm{Cl}^{-}\right)$} & Linear: $\varepsilon=3.2888 \times 10^{-1}-5.9746 \times 10^{-4} \mathrm{~T}\left(\mathrm{R}^{2}=0.9734\right)$ & 0.016 & $0.3-6.0$ & $298.15-473.15 \mathrm{~K}$ at $\mathrm{P}_{\mathrm{SAT}}$ \\
\hline & Polynomial: $\varepsilon=5.2527 \times 10^{-2}+8.8048 \times 10^{-4} \mathrm{~T}-1.9207 \times 10^{-6} \mathrm{~T}^{2}\left(\mathrm{R}^{2}=0.9970\right)$ & & & \\
\hline \multirow[t]{2}{*}{$\varepsilon\left(\mathrm{Sr}^{2+}, \mathrm{Cl}^{-}\right)$} & Linear: $\varepsilon=3.2226 \times 10^{-1}-5.5384 \times 10^{-4} \mathrm{~T}\left(\mathrm{R}^{2}=0.980 \mathrm{I}\right)$ & 0.014 & $0.3-6.0$ & $298.15-473.15 \mathrm{~K}$ at $\mathrm{P}_{\mathrm{SAT}}$ \\
\hline & Polynomial: $\varepsilon=1.2297 \times 10^{-1}+5.1201 \times 10^{-4} \mathrm{~T}-1.3852 \times 10^{-6} \mathrm{~T}^{2}\left(\mathrm{R}^{2}=0.9945\right)$ & & & \\
\hline \multirow[t]{2}{*}{$\varepsilon\left(\mathrm{Ba}^{2+}, \mathrm{Cl}-\right)$} & Linear: $\varepsilon=2.0474 \times 10^{-1}-4.1667 \times 10^{-4} \mathrm{~T}\left(\mathrm{R}^{2}=0.9584\right)$ & 0.014 & $0.3-9.0$ & $298.15-423.15 \mathrm{~K}$ at $\mathrm{P}_{\mathrm{SAT}}$ \\
\hline & Polynomial: $\varepsilon=-1.1827 \times 10^{-1}+1.4053 \times 10^{-3} \mathrm{~T}-2.5230 \times 10^{-6} \mathrm{~T}^{2}\left(\mathrm{R}^{2}=0.9985\right)$ & & & \\
\hline \multirow[t]{2}{*}{$\varepsilon\left(\mathrm{Ba}^{2+}, \mathrm{Cl}^{-}\right)$} & Linear: $\varepsilon=2.0491 \times 10^{-1}-4.0566 \times 10^{-4} \mathrm{~T}\left(\mathrm{R}^{2}=0.9599\right)$ & 0.013 & $0.3-9.0$ & $298.15-423.15 \mathrm{~K}$ at 200 bars \\
\hline & Polynomial: $\varepsilon=-1.0310 \times 10^{-1}+1.3317 \times 10^{-3} \mathrm{~T}-2.4058 \times 10^{-6} \mathrm{~T}^{2}\left(\mathrm{R}^{2}=0.9985\right)$ & & & \\
\hline \multirow[t]{2}{*}{$\varepsilon\left(\mathrm{Ba}^{2+}, \mathrm{Cl}^{-}\right)$} & Linear: $\varepsilon=2.0325 \times 10^{-1}-3.9039 \times 10^{-4} \mathrm{~T}\left(\mathrm{R}^{2}=0.9621\right)$ & 0.030 & $0.3-9.0$ & $298.15-423.15 \mathrm{~K}$ at 200 bars \\
\hline & Polynomial: $\varepsilon=-8.3861 \times 10^{-2}+1.2291 \times 10^{-3} \mathrm{~T}-2.2426 \times 10^{-6} \mathrm{~T}^{2}\left(\mathrm{R}^{2}=0.9984\right)$ & & & \\
\hline \multirow[t]{2}{*}{$\varepsilon\left(\mathrm{Sm}^{3+}, \mathrm{Cl}^{-}\right)$} & Linear: $\varepsilon=5.5890 \times 10^{-1}-1.1536 \times 10^{-3} \mathrm{~T}\left(\mathrm{R}^{2}=0.9895\right)$ & 0.016 & $0.51-6.0$ & $273.15-338.15 \mathrm{~K}$ at I bar \\
\hline & Polynomial: $\varepsilon=3.0000 \times 10^{-1}+5.3392 \times 10^{-4} \mathrm{~T}-2.738 \mathrm{I} \times 10^{-6} \mathrm{~T}^{2}\left(\mathrm{R}^{2}=0.991 \mathrm{I}\right)$ & & & \\
\hline$\varepsilon\left(\mathrm{Eu}^{3+}, \mathrm{Cl}^{-}\right)$ & $\varepsilon=-4.8708 \times 10^{-1}+4.8872 \times 10^{-3} \mathrm{~T}-8.3929 \times 10^{-6} \mathrm{~T}^{2}\left(\mathrm{R}^{2}=0.9950\right)$ & 0.016 & $0.51-6.0$ & $273.15-338.15 \mathrm{~K}$ at I bar \\
\hline \multirow[t]{2}{*}{$\varepsilon\left(\mathrm{Gd}^{3+}, \mathrm{Cl}^{-}\right)$} & Linear: $\varepsilon=4.3225 \times 10^{-1}-6.9179 \times 10^{-4} \mathrm{~T}\left(\mathrm{R}^{2}=0.968 \mathrm{I}\right)$ & 0.016 & $0.51-6.0$ & $273.15-338.15 \mathrm{~K}$ at I bar \\
\hline & Polynomial: $\varepsilon=2.5104 \times 10^{-1}+3.7617 \times 10^{-3} \mathrm{~T}-7.2262 \times 10^{-6} \mathrm{~T}^{2}\left(\mathrm{R}^{2}=0.9998\right)$ & & & \\
\hline$\varepsilon\left(\mathrm{GdAc}^{2+}, \mathrm{Cl}^{-}\right)$ & $\varepsilon=0.12$ & 0.04 & $0.1-2.0$ & $298.15-338.15 \mathrm{~K}$ at I bar \\
\hline$\varepsilon\left(\mathrm{Li}^{+}, \mathrm{OH}^{-}\right)$ & $\varepsilon=1.5802 \times 10^{-1}-5.4117 \times 10^{-4} \mathrm{~T}\left(\mathrm{R}^{2}=0.9974\right)$ & 0.02 & $0.1-5.0$ & $298.15-473.15 \mathrm{~K}$ at $\mathrm{P}_{\mathrm{SAT}}$ \\
\hline$\varepsilon\left(\mathrm{Na}^{+}, \mathrm{OH}^{-}\right)$ & $\varepsilon=-1.5573 \times 10^{-1}+1.4279 \times 10^{-3} \mathrm{~T}-2.4094 \times 10^{-6} \mathrm{~T}^{2}\left(\mathrm{R}^{2}=0.9987\right)$ & 0.0092 & $0.1-5.0$ & $273.15-473.15 \mathrm{~K}$ at $\mathrm{P}_{\mathrm{SAT}}$ \\
\hline$\varepsilon\left(\mathrm{K}^{+}, \mathrm{OH}^{-}\right)$ & $\varepsilon=2.6120 \times 10^{-1}-5.4520 \times 10^{-4} \mathrm{~T}\left(\mathrm{R}^{2}=0.9924\right)$ & 0.0043 & $0.1-5.0$ & $273.15-423.15 \mathrm{~K}$ at $\mathrm{P}_{\mathrm{SAT}}$ \\
\hline$\varepsilon\left(\mathrm{Cs}^{+}, \mathrm{OH}^{-}\right)$ & $\varepsilon=2.0759 \times 10^{-1}-3.3855 \times 10^{-4} \mathrm{~T}\left(\mathrm{R}^{2}=0.9700\right)$ & 0.0054 & $0.1-5.0$ & $273.15-423.15 \mathrm{~K}$ at $\mathrm{P}_{\mathrm{SAT}}$ \\
\hline \multirow[t]{2}{*}{$\varepsilon\left(\mathrm{Na}^{+}, \mathrm{Ac}^{-}\right)$} & Linear: $\varepsilon=1.4784 \times 10^{-1}-3.6016 \times 10^{-4} \mathrm{~T}\left(\mathrm{R}^{2}=0.9928\right)$ & 0.0070 & $0.1-5.0$ & $298.15-448.15 \mathrm{~K}$ at $\mathrm{P}_{\mathrm{SAT}}$ \\
\hline & Polynomial: $\varepsilon=3.700 \mathrm{I} \times 10^{-1}+2.5583 \times 10^{-4} \mathrm{~T}-8.3336 \times 10^{-7} \mathrm{~T}^{2}\left(\mathrm{R}^{2}=0.9933\right)$ & & & \\
\hline
\end{tabular}

\section{Equilibrium quotient data}

Similar to the sigma value defined for comparison of mean activity coefficients, the sigma value for the difference in equilibrium quotient is defined as:

$\sigma=\sqrt{\sum_{i=1}^{n} \frac{\left(\log Q_{\text {exp }}-\log Q_{\text {pread }}\right)^{2}}{n}}$

where $\log Q_{\exp }$ is the experimental equilibrium quotient at certain ionic strength (in molality) in logarithmic unit, $\log Q_{\text {pred }}$ is the equilibrium quotient at the same strength in logarithmic unit predicted by using the SIT model.

The first example is to compare the solubility equilibrium quotients of brucite in $\mathrm{NaCl}, \mathrm{NaCl}+\mathrm{MgCl}_{2}$ and $\mathrm{MgCl}_{2}$ solutions with ionic strength up to $8 \mathrm{~m}$ at temperatures up to $200^{\circ} \mathrm{C}$. The solubility equilibrium of brucite can be expressed as:

$$
\mathrm{Mg}(\mathrm{OH})_{2}(\mathrm{~s})+2 \mathrm{H}^{+}=\mathrm{Mg}^{2+}+2 \mathrm{H}_{2} \mathrm{O}(\mathrm{l})
$$

The expression for the equilibrium constant at infinite dilution can be written as:

$$
\begin{aligned}
& \log \mathrm{K}^{\circ}=\log \mathrm{Q}-2 \mathrm{D}+\varepsilon\left(\mathrm{Mg}^{2+}, \mathrm{Cl}^{-}\right) \mathrm{I}_{\mathrm{m}}-2 \varepsilon\left(\mathrm{H}^{+}, \mathrm{Cl}^{-}\right) \mathrm{I}_{\mathrm{m}}+2 \\
& \log \mathrm{a}_{\mathrm{H}_{2} \mathrm{O}}
\end{aligned}
$$

Rearrangement of Eq. (24) gives: 


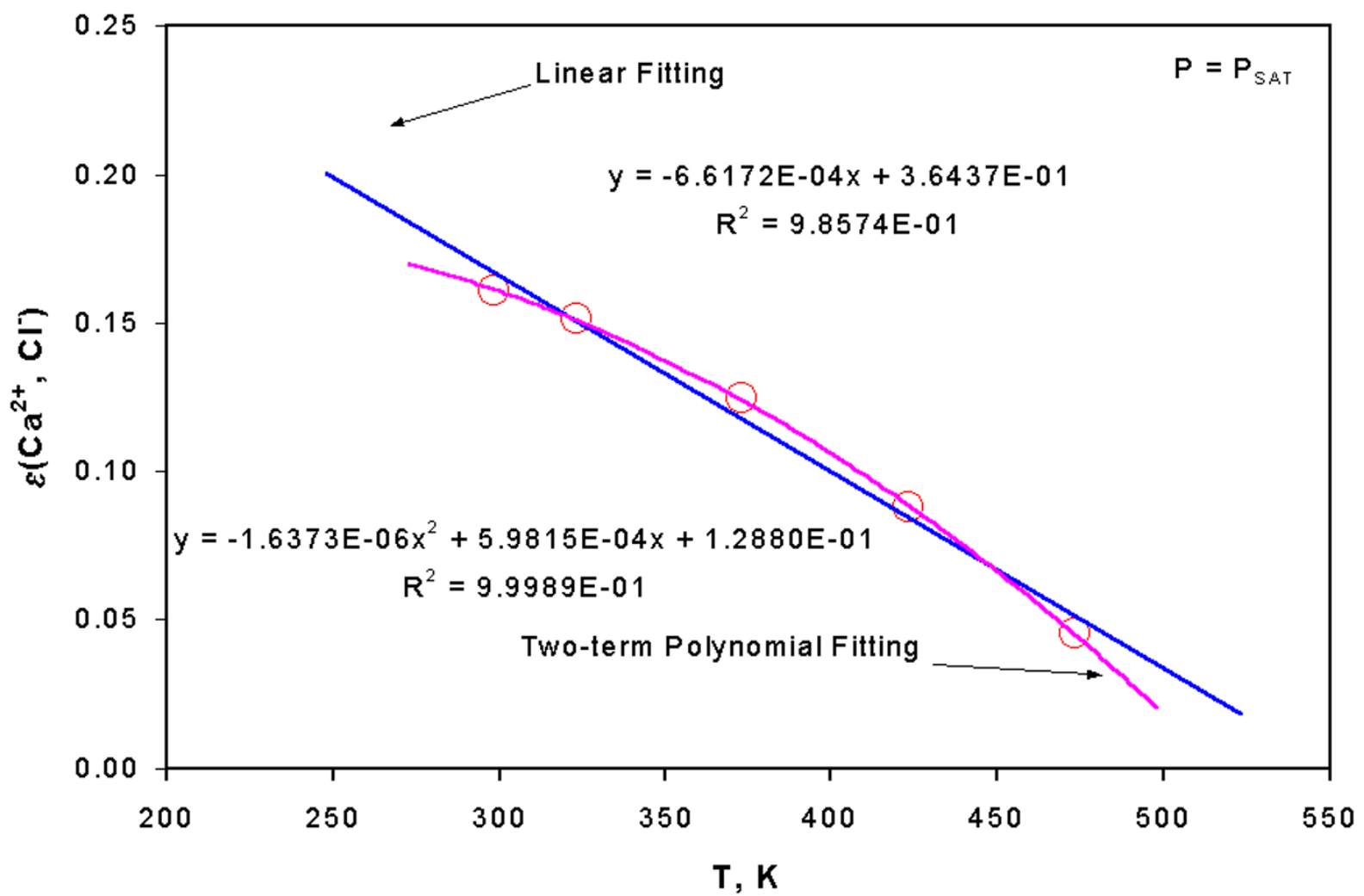

Figure 2

A plot showing $\varepsilon\left(\mathrm{Ca}^{2+}, \mathrm{Cl}^{-}\right)$as a function of temperature at saturated vapor pressures.

$\log \mathrm{Q}=\log \mathrm{K}^{\circ}+2 \mathrm{D}-\varepsilon\left(\mathrm{Mg}^{2+}, \mathrm{Cl}^{-}\right) \mathrm{I}_{\mathrm{m}}+2 \varepsilon\left(\mathrm{H}^{+}, \mathrm{Cl}^{-}\right) \mathrm{I}_{\mathrm{m}}-2$

$\log \mathrm{a}_{\mathrm{H}_{2} \mathrm{O}}$

Therefore, according to the interaction coefficients recommended by this study and the equilibrium constant at infinite dilution, the equilibrium quotient at certain ionic strength can be predicted.

Altmaier et al. [79] determined solubility equilibrium quotient of brucite in $\mathrm{NaCl}$ and $\mathrm{MgCl}_{2}$ solutions, and they obtained its solubility constant at infinite dilution $\left(\log \mathrm{K}^{\circ}\right)$ by extrapolation by using the Pitzer equations as $17.1 \pm 0.2$.

In Eq. (25), the activity of water in $\mathrm{NaCl}$ solutions at $25^{\circ} \mathrm{C}$ is taken from Robinson and Stokes [22] and in $\mathrm{MgCl}_{2}$ solutions is taken from Rard and Miller [53], and $\log \mathrm{K}^{\circ}$ $(17.1 \pm 0.2)$ is taken from Altmaier et al. [79]. It is obvious from Figure 3 that the interaction coefficients of $\varepsilon\left(\mathrm{Mg}^{2+}\right.$, $\left.\mathrm{Cl}^{-}\right)$and $\varepsilon\left(\mathrm{H}^{+}, \mathrm{Cl}^{-}\right)$evaluated by this study can reproduce within the experimental uncertainty the solubility equilibrium quotients of brucite at ionic strength up to $8.0 \mathrm{~m}$ in $\mathrm{NaCl}, \mathrm{NaCl}+\mathrm{MgCl}_{2}$ and $\mathrm{MgCl}_{2}$ solutions at $25^{\circ} \mathrm{C}$. Additionally, it may be worth noting that in the extrapolation of their experimental data to infinite dilution by using the Pitzer equations, Altmaier et al. [79] employed 20 Pitzer parameters (12 binary interaction parameters and 8 ternary/mixing interaction parameters) to describe fully their experimental system when $\mathrm{MgOH}^{+}$is ignored. In contrast, only 2 parameters are needed to describe fully the experimental system by the SIT. Therefore, the SIT is mathematically simpler, and is able to describe the system with the reasonable accuracy.

Brown et al. [80] determined by potentiometric titration the solubility equilibrium quotients of brucite in $0.1 \mathrm{~m}$ and $1.0 \mathrm{~m} \mathrm{NaCl}$ solution at $60,100,150$, and $200^{\circ} \mathrm{C}$. In calculations of equilibrium quotients, activity of water in Eq. (25) below $75^{\circ} \mathrm{C}$ is taken from Gibbard et al. [25], and at $\mathrm{T} \geq 75^{\circ} \mathrm{C}$ is taken from Liu and Lindsay [42], and the $\log \mathrm{K}^{\circ}$ at the above temperatures are taken from Brown et al. [80]. It can be seen from Figure 4 that the predicted equilibrium quotients are in agreement with the experimental values within the experimental uncertainty, as differences are less than $\pm 0.04 \log$ units, and the two 


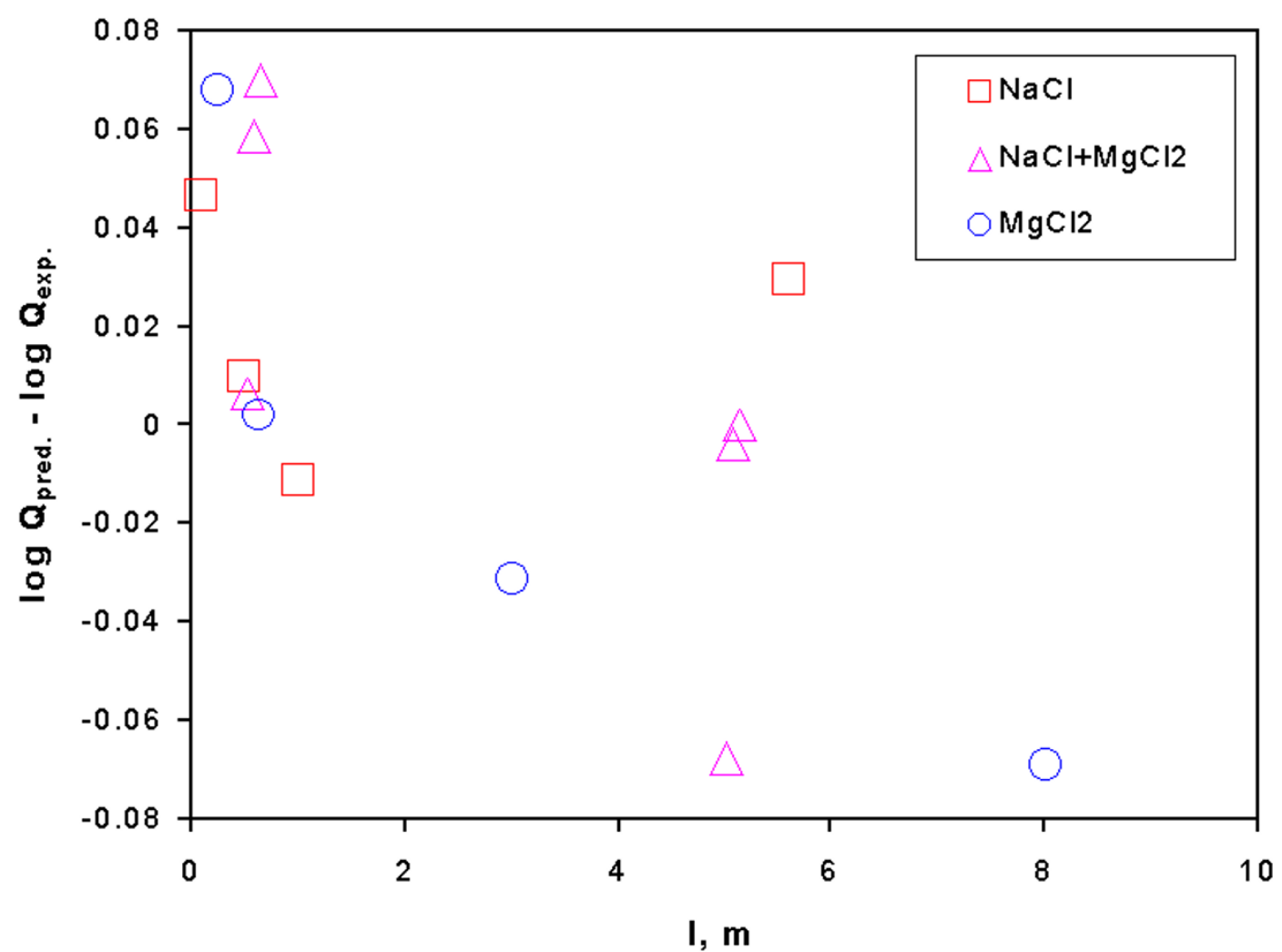

Figure 3

A plot showing the comparison of predicted solubility quotients of brucite with those determined by experimental studies in $\mathrm{NaCl}, \mathrm{NaCl}+\mathrm{MgCl}_{2}$ and $\mathrm{MgCl}_{2}$ solutions at $25^{\circ} \mathrm{C}$. Experimental solubility quotients are from Altmaier et al. 79.

standard deviations $(2 \sigma)$ associated with their equilibrium quotients are \pm 0.04 . In addition, solubility quotients of brucite are also predicted by using the $\mathrm{B}$ dot equation [9] for comparison (Figure 4). In using the B dot equation, the ion size parameters for $\mathrm{Mg}^{2+}$ and $\mathrm{H}^{+}$are from the compilation of Wolery [10], and B dot parameters are from Helgeson [9]. It seems clear from Figure 4 that all of the differences between solubility quotients predicted by the $\mathrm{B}$ dot equation and those determined by the experimental studies exceed \pm 0.04 log units except one data point in $0.1 \mathrm{~m} \mathrm{NaCl}$ solution at $60^{\circ} \mathrm{C}$, which is within the experimental uncertainty of $\pm 0.04 \log$ units. Therefore, the SIT model performs better than the B dot equation does even in the ionic strength range valid for the $\mathrm{B}$ dot equation, although the $\mathrm{B}$ dot equation does have the general applicability as it does not require any specific interaction coefficients.

The second case is to compare the predicted solubility of cerargyrite, $\mathrm{AgCl}(\mathrm{s})$, in $1.0 \mathrm{~m} \mathrm{HCl}$ at $100^{\circ} \mathrm{C}$ with the experimental solubility of Gammons and Seward [81].
The following two considerations are taken into account into choosing to compare the solubility of $\mathrm{AgCl}(\mathrm{s})$ in 1.0 $\mathrm{m} \mathrm{NaCl}$ solution at $100^{\circ} \mathrm{C}$. The first consideration is that that $\mathrm{AgCl}_{2}$ - is the dominant species in $1.0 \mathrm{~m} \mathrm{NaCl}$ solution at $100^{\circ} \mathrm{C}[41]$. The second consideration is that the association of $\mathrm{H}^{+}$with $\mathrm{Cl}^{-}$to form ion pair $\mathrm{HCl}^{\circ}$ is insignificant at this temperature [82]. These two facts will contribute to the simplification of the comparison. It also should be mentioned that the data of Gammons and Seward [81] have not been used to derive interaction coefficients in this study. Therefore, they are independent of interaction coefficients derived from Seward [41].

The solubility of $\mathrm{AgCl}(\mathrm{s})$ as $\mathrm{AgCl}_{2}$ - can be expressed as:

$$
\begin{aligned}
& \operatorname{AgCl}(\mathrm{s})+\mathrm{Cl}^{-}=\mathrm{AgCl}_{2}{ }^{-} \\
& \log \mathrm{K}_{\mathrm{s} 2}^{\circ}=-3.19 \pm 0.16(2 \sigma)
\end{aligned}
$$

The above $\log \mathrm{K}_{\mathrm{s} 2}^{\circ}$ at infinite dilution at $100^{\circ} \mathrm{C}$ is obtained by combination of $\log \mathrm{K}^{\circ}{ }_{\mathrm{s} 0}$ and $\log \beta^{\circ}{ }_{2}$ of 
Table 8: Comparison of mean activity coefficients predicted by using SIT with experimental values

\begin{tabular}{|c|c|c|}
\hline System & Experimental Data Sets* & Sigma Value $\sigma$ \\
\hline \multirow[t]{4}{*}{$\mathrm{HCl}-\mathrm{H}_{2} \mathrm{O}$} & Robinson and Harned [46]: $\mathrm{m}_{\mathrm{HCl}}=0.000 \mathrm{I}-4.0, \mathrm{~T}=0-60^{\circ} \mathrm{C}$ & 0.0194 \\
\hline & Bates and Bower [47]: $\mathrm{m}_{\mathrm{HCl}}=0.00 \mathrm{I}-1.0, \mathrm{~T}=0-90^{\circ} \mathrm{C}$ & 0.0121 \\
\hline & Greeley et al. [23]: $\mathrm{m}_{\mathrm{HCl}}=0.00 \mathrm{I}-1.0, \mathrm{~T}=60-200^{\circ} \mathrm{C}$ & 0.0081 \\
\hline & Roy et al. [48]: $\mathrm{m}_{\mathrm{HCl}}=0.005-4.0, \mathrm{~T}=0-45^{\circ} \mathrm{C}$ & 0.0171 \\
\hline \multirow[t]{3}{*}{$\mathrm{NaCl}-\mathrm{H}_{2} \mathrm{O}$} & Robinson and Harned [46]: $\mathrm{m}_{\mathrm{NaCl}}=0.1-4.0, \mathrm{~T}=0-100^{\circ} \mathrm{C}$ & 0.0295 \\
\hline & Liu and Lindsay [42]: $\mathrm{m}_{\mathrm{NaCl}}=0.05-6.0, \mathrm{~T}=75-200^{\circ} \mathrm{C}$ & 0.0167 \\
\hline & Busey et al. [49]: $\mathrm{m}_{\mathrm{NaCl}}=0.1-5.0, \mathrm{~T}=100-200^{\circ} \mathrm{C}$ & 0.0135 \\
\hline $\mathrm{HCl}-\mathrm{MgCl}_{2}-\mathrm{H}_{2} \mathrm{O}$ & White et al. [50]: $\mathrm{m}_{\mathrm{HCl}}=0.01-0.7848, \mathrm{~m}_{\mathrm{MgCl}}=0.0033-0.2616 ; \mathrm{T}=0-45^{\circ} \mathrm{C}$ & $\gamma_{\mathrm{HCl}}: 0.0114$ \\
\hline $\mathrm{HCl}-\mathrm{BaCl}_{2}-\mathrm{H}_{2} \mathrm{O}$ & Roy et al. [48]: $\mathrm{m}_{\mathrm{HCl}}=0.0025-2.0, \mathrm{~m}_{\mathrm{BaCl} 2}=0.000833-0.667 ; \mathrm{T}=0-45^{\circ} \mathrm{C}$ & $\gamma_{\mathrm{HCl}}: 0.0391 \gamma_{\mathrm{BaCl} 2}: 0.0180$ \\
\hline \multirow[t]{5}{*}{$\mathrm{MgCl}_{2}-\mathrm{H}_{2} \mathrm{O}$} & $\operatorname{Pan}[5 \mathrm{I}]: \mathrm{m}_{\mathrm{MgCl}}=0.000 \mathrm{I}-0.1, \mathrm{~T}=25^{\circ} \mathrm{C}$ & 0.0011 \\
\hline & Goldberg and Nuttall [52]: $\mathrm{m}_{\mathrm{MgCl} 2}=0.00 \mathrm{I}-2.0, \mathrm{~T}=25^{\circ} \mathrm{C}$ & 0.0164 \\
\hline & Rard and Miller [53]: $\mathrm{m}_{\mathrm{MgCl} 2}=0 . \mathrm{I}-2.0, \mathrm{~T}=25^{\circ} \mathrm{C}$ & 0.0348 \\
\hline & Wang et al. [54]: $\mathrm{m}_{\mathrm{MgCl} 2}=0.00 \mathrm{I}-2.0, \mathrm{~T}=100-200^{\circ} \mathrm{C}$ (theoretical fit) & 0.0111 \\
\hline & El Guendouzi et al. [55]: $\mathrm{m}_{\mathrm{MgCl} 2}=0.2-2.0, \mathrm{~T}=25^{\circ} \mathrm{C}$ & 0.0322 \\
\hline \multirow[t]{9}{*}{$\mathrm{CaCl}_{2}-\mathrm{H}_{2} \mathrm{O}$} & McLeod and Gordon [56]: $\mathrm{m}_{\mathrm{CaCl} 2}=0.0016-0.0784, \mathrm{~T}=15^{\circ} \mathrm{C}-35^{\circ} \mathrm{C}$ & 0.0006 \\
\hline & Robinson [57]: $\mathrm{m}_{\mathrm{CaCl}}=0.1-2.2, \mathrm{~T}=25^{\circ} \mathrm{C}$ & 0.025 \\
\hline & Stokes [58]: $\mathrm{m}_{\mathrm{CaCl} 2}=0.1-3.0, \mathrm{~T}=25^{\circ} \mathrm{C}$ & 0.0200 \\
\hline & Shedlovsky [59]: $\mathrm{m}_{\mathrm{CaCl} / 2}=0.00 \mathrm{I}-0.1, \mathrm{~T}=25^{\circ} \mathrm{C}$ & 0.0039 \\
\hline & Robinson and Stokes [22]: $\mathrm{m}_{\mathrm{CaCl}}=0.1-3.0, \mathrm{~T}=25^{\circ} \mathrm{C}$ & 0.0200 \\
\hline & Staples and Nuttall $[60]: \mathrm{m}_{\mathrm{CaCl} 2}=0.00 \mathrm{I}-3.0, \mathrm{~T}=25^{\circ} \mathrm{C}$ & 0.0145 \\
\hline & Rard and Clegg [6I]: $\mathrm{m}_{\mathrm{CaCl} 2}=0.00 \mathrm{I}-3.0, \mathrm{~T}=25^{\circ} \mathrm{C}$ & 0.0159 \\
\hline & El Guendouzi et al. [55]: $\mathrm{m}_{\mathrm{CaCl} 2}=0.2-3.0, \mathrm{~T}=25^{\circ} \mathrm{C}$ & 0.0205 \\
\hline & Gruszkiewicz and Simonson [62]: $\mathrm{m}_{\mathrm{CaCl}}=0.01-3.0, \mathrm{~T}=50^{\circ} \mathrm{C}-200^{\circ} \mathrm{C}$ & 0.0110 \\
\hline \multirow[t]{6}{*}{$\mathrm{SrCl}_{2}-\mathrm{H}_{2} \mathrm{O}$} & Harned and Åkerlöf [63]: $\mathrm{m}_{\mathrm{SrCl} 2}=0.0 \mathrm{I}-1.0, \mathrm{~T}=25^{\circ} \mathrm{C}$ & 0.0280 \\
\hline & Phillips et al. [64]: $\mathrm{m}_{\mathrm{SrCl} 2}=0.05-1.3, \mathrm{~T}=25^{\circ} \mathrm{C}$ & 0.0414 \\
\hline & Robinson and Stokes $[22]: \mathrm{m}_{\mathrm{SrCl} 2}=0.1-3.0, \mathrm{~T}=25^{\circ} \mathrm{C}$ & 0.0404 \\
\hline & Longhi et al. [65]: $\mathrm{m}_{\mathrm{SrCl} / 2}=0.000 \mathrm{I}-0.3, \mathrm{~T}=10^{\circ} \mathrm{C}-70^{\circ} \mathrm{C}$ & 0.0109 \\
\hline & $\operatorname{Pan}[5 \mathrm{I}]: \mathrm{m}_{\mathrm{SrCl} 2}=0.000 \mathrm{I}-0.1, \mathrm{~T}=25^{\circ} \mathrm{C}$ & 0.0012 \\
\hline & Goldberg and Nuttall [52]: $\mathrm{m}_{\mathrm{SrCl} 2}=0.00 \mathrm{I}-3.0, \mathrm{~T}=25^{\circ} \mathrm{C}$ & 0.0401 \\
\hline \multirow[t]{2}{*}{$\mathrm{BaCl}_{2}-\mathrm{H}_{2} \mathrm{O}$} & Tippetts and Newton [66]: $\mathrm{m}_{\mathrm{BaCl}}=0.01-1.8, \mathrm{~T}=0^{\circ} \mathrm{C}-45^{\circ} \mathrm{C}$ & \\
\hline & Ardizzone et al. [67]: $\mathrm{m}_{\mathrm{BaCl} / 2}=0.000 \mathrm{I}-0.3, \mathrm{~T}=10^{\circ} \mathrm{C}-70^{\circ} \mathrm{C}$ & \\
\hline \multirow[t]{3}{*}{$\mathrm{SmCl}_{3}-\mathrm{H}_{2} \mathrm{O}$} & Mason [68]: $\mathrm{m}_{\mathrm{SmCl} 3}=0.05-1.0, \mathrm{~T}=25^{\circ} \mathrm{C}$ & 0.0218 \\
\hline & Robinson and Stokes [22]: $\mathrm{m}_{\mathrm{SmCl} 3}=0.1-1.0, \mathrm{~T}=25^{\circ} \mathrm{C}$ & 0.0334 \\
\hline & Spedding et al. [69]: $\mathrm{m}_{\mathrm{SmCl} 3}=0.1-1.0, \mathrm{~T}=25^{\circ} \mathrm{C}$ & 0.0247 \\
\hline \multirow[t]{3}{*}{$\mathrm{EuCl}_{3}-\mathrm{H}_{2} \mathrm{O}$} & Mason [68]: $\mathrm{m}_{\mathrm{EuCl} 3}=0.05-1.0, \mathrm{~T}=25^{\circ} \mathrm{C}$ & 0.0220 \\
\hline & Robinson and Stokes [22]: $\mathrm{m}_{\mathrm{EuCl}}=0 . \mathrm{I}-1.0, \mathrm{~T}=25^{\circ} \mathrm{C}$ & 0.0317 \\
\hline & Spedding et al. [69]: $\mathrm{m}_{\mathrm{EuCl}}=0.1-1.0, \mathrm{~T}=25^{\circ} \mathrm{C}$ & 0.0254 \\
\hline $\mathrm{GdCl}_{3}-\mathrm{H}_{2} \mathrm{O}$ & Spedding et al. [69]: $\mathrm{m}_{\mathrm{EuCl}}=0.1-1.0, \mathrm{~T}=25^{\circ} \mathrm{C}$ & 0.0247 \\
\hline \multirow[t]{2}{*}{$\mathrm{LiOH}-\mathrm{H}_{2} \mathrm{O}$} & Kangro and Groeneveld [70]: $\mathrm{m}_{\mathrm{LiOH}}=0.5-2.0, \mathrm{~T}=25^{\circ} \mathrm{C}$ & 0.0375 \\
\hline & Hamer and $\mathrm{Wu}[7 \mathrm{I}]: \mathrm{m}_{\mathrm{LiOH}}=0.00 \mathrm{I}-2.0, \mathrm{~T}=25^{\circ} \mathrm{C}$ & 0.0290 \\
\hline \multirow[t]{5}{*}{$\mathrm{NaOH}-\mathrm{H}_{2} \mathrm{O}$} & Harned [72]: $\mathrm{m}_{\mathrm{NaOH}}=0.0202-3.1, \mathrm{~T}=25^{\circ} \mathrm{C}$ & 0.0174 \\
\hline & Harned and Akerlöf [63]: $\mathrm{m}_{\mathrm{NaOH}}=0.0053-3.1, \mathrm{~T}=25^{\circ} \mathrm{C}$ & 0.0274 \\
\hline & Åkerlöf and Kegeles [73]: $\mathrm{m}_{\mathrm{NaOH}}=0.1-5.0, \mathrm{~T}=0-70^{\circ} \mathrm{C}$ & 0.0382 \\
\hline & Robinson and Stokes [22]: $\mathrm{m}_{\mathrm{NaOH}}=0.1-5.0, \mathrm{~T}=25^{\circ} \mathrm{C}$ & 0.0365 \\
\hline & Hamer and $\mathrm{Wu}[7 \mathrm{I}]: \mathrm{m}_{\mathrm{NaOH}}=0.00 \mathrm{I}-5.0, \mathrm{~T}=25^{\circ} \mathrm{C}$ & 0.0298 \\
\hline $\mathrm{KOH}-\mathrm{H}_{2} \mathrm{O}$ & Knobel $[74]: \mathrm{m}_{\mathrm{KOH}}=0.00 \mathrm{I}-3.0, \mathrm{~T}=25^{\circ} \mathrm{C}$ & 0.0178 \\
\hline
\end{tabular}


Table 8: Comparison of mean activity coefficients predicted by using SIT with experimental values (Continued)

\begin{tabular}{lll}
\hline & Scatchard [75]: $\mathrm{m}_{\mathrm{KOH}}=0.00 \mathrm{I}-\mathrm{I} .0, \mathrm{~T}=25^{\circ} \mathrm{C}$ & 0.0209 \\
& Harned and Ákerlöf [63]: $\mathrm{m}_{\mathrm{KOH}}=0.0 \mathrm{I}-\mathrm{I.0}, \mathrm{T}=25^{\circ} \mathrm{C}$ & 0.0201 \\
& Harned and Cook [76]: $\mathrm{m}_{\mathrm{KOH}}=0.1-4.0, \mathrm{~T}=0^{\circ} \mathrm{C}-35^{\circ} \mathrm{C}$ & 0.0345 \\
& Robinson and Harned [46]: $\mathrm{m}_{\mathrm{KOH}}=0.05-4.0, \mathrm{~T}=25^{\circ} \mathrm{C}$ & 0.0207 \\
& Robinson and Stokes [22]: $\mathrm{m}_{\mathrm{KOH}}=0.1-5.0, \mathrm{~T}=25^{\circ} \mathrm{C}$ & 0.0422 \\
& Hamer and Wu [7I]: $\mathrm{m}_{\mathrm{KOH}}=0.00 \mathrm{I}-5.0, \mathrm{~T}=25^{\circ} \mathrm{C}$ & 0.0377 \\
$\mathrm{CsOH}-\mathrm{H}_{2} \mathrm{O}$ & & 0.0129 \\
& Harned and Schupp [77]: $\mathrm{m}_{\mathrm{CsOH}}=0.01016-1.3205, \mathrm{~T}=25^{\circ} \mathrm{C}$ & $0.017 \mathrm{I}$ \\
& Robinson and Stokes [78]: $\mathrm{m}_{\mathrm{CsOH}}=0.1-1.0, \mathrm{~T}=25^{\circ} \mathrm{C}$ & 0.0083 \\
& Robinson and Stokes [22]: $\mathrm{m}_{\mathrm{CsOH}}=0.1-1.0, \mathrm{~T}=25^{\circ} \mathrm{C}$ & 0.0086
\end{tabular}

* Multiple experimental data sets in the same system are listed in chronological order.

Seward [41], and the uncertainty is calculated as two standard deviations $(2 \sigma)$ and error propagation is taken into consideration. According to Reaction (26), the relation between $\log \mathrm{K}_{\mathrm{s} 2}^{\circ}$ and $\log \mathrm{Q}_{\mathrm{s} 2}$ can be written as:

$\log \mathrm{Q}_{\mathrm{s} 2}=\log \mathrm{K}_{\mathrm{s} 2}^{\circ}-\varepsilon\left(\mathrm{H}^{+}, \mathrm{AgCl}_{2}{ }^{-}\right)+\varepsilon\left(\mathrm{H}^{+}, \mathrm{Cl}^{-}\right)$

When $\log \mathrm{Q}_{\mathrm{s} 2}$ is calculated, it is assumed that $\varepsilon\left(\mathrm{H}^{+}, \mathrm{AgCl}_{2}\right.$ $-) \cong \varepsilon\left(\mathrm{Na}^{+}, \mathrm{AgCl}_{2}{ }^{-}\right)$. The calculated $\log \mathrm{Q}_{\mathrm{s} 2}$ at $1.0 \mathrm{~m} \mathrm{HCl}$ is $-3.08 \pm 0.16(2 \sigma)$. Therefore, the predicted solubility of $\mathrm{AgCl}\left(\mathrm{s}\right.$ ) in $1.0 \mathrm{~m} \mathrm{HCl}$ at $100^{\circ} \mathrm{C}$ is $10^{-3.08 \pm 0.16} \mathrm{~m}$ (see Table 9 ). Notice that the uncertainty is inherited from $\log \mathrm{K}_{\mathrm{s} 2}^{\circ}$. The measured solubility of Gammons and Seward [81] in the same solution at the same temperature is $10^{-2.88} \mathrm{~m}$. In the above calculations, the small contributions from $\mathrm{AgCl}^{\circ}, \mathrm{AgCl}_{3}{ }^{-2}$ and $\mathrm{AgCl}_{4}{ }^{-3}$ are ignored. Accordingly, when contributions from $\mathrm{AgCl}^{\circ}, \mathrm{AgCl}_{3}{ }^{-2}$ and $\mathrm{AgCl}_{4}{ }^{-3}$ are considered, the predicted solubility of $\mathrm{Ag}(\mathrm{s})$ in $1.0 \mathrm{~m} \mathrm{HCl}$ would be in satisfactory agreement with the measured solubility.

In addition, $\log \mathrm{Q}_{\mathrm{s} 2}$ in $3.0 \mathrm{~m} \mathrm{HCl}$ at $100^{\circ} \mathrm{C}$ is also predicted according to Reaction (26) (Table 9). By using log $\mathrm{Q}_{\mathrm{s} 2}$ in $3.0 \mathrm{~m} \mathrm{HCl}$ at $100^{\circ} \mathrm{C}$, the solubility of $\mathrm{AgCl}(\mathrm{s})$ can be satisfactorily predicted by assuming the sole contribution from $\mathrm{AgCl}_{2}$ - (Table 9), as the predicted solubility is $10^{-2.40 \pm 0.16} \mathrm{~m}$ in comparison with the measured solubility of $10^{-2.23} \mathrm{~m}$. Therefore, the dominance field of $\mathrm{AgCl}_{2}-$ may well be extended to chloride concentrations of $3.0 \mathrm{~m}$.

Table 9: Predicted solubility quotient of $\mathrm{AgCl}(\mathrm{s})$, and predicted and measured solubility of $\mathrm{AgCl}(\mathrm{s})$, in $\mathrm{HCl}$ solutions at $100^{\circ} \mathrm{C}$

\begin{tabular}{llll}
\hline $\mathrm{I}, \mathrm{m}_{\mathrm{HCl}}$ & $\log \mathrm{Q}_{\mathrm{s} 2}$ & $\begin{array}{l}\text { Predicted } \\
\text { Solubility, } \mathrm{m}\end{array}$ & $\begin{array}{l}\text { Measured Solubility, } \mathrm{m}, \\
\text { from Gammons and } \\
\text { Seward [8I] }\end{array}$ \\
\hline 1.0 & $-3.08 \pm 0.16$ & $10^{-3.08 \pm 0.16}$ & $10^{-2.88}$ \\
2.0 & $-2.98 \pm 0.16$ & $10^{-2.68 \pm 0.16}$ & $\begin{array}{l}\text { Not measured } \\
10^{-2.23}\end{array}$ \\
3.0 & $-2.87 \pm 0.16$ & $10^{-2.40 \pm 0.16}$ & \\
\hline
\end{tabular}

The third case is the comparison of the ionization of water in $\mathrm{LiCl}, \mathrm{NaCl}$ and $\mathrm{KCl}$ solutions ranging from $0.1 \mathrm{~m}$ to 5.0 $\mathrm{m}$ at temperatures up to $200^{\circ} \mathrm{C}$ determined by various researchers with the values predicted by using $\varepsilon\left(\mathrm{H}^{+}, \mathrm{Cl}^{-}\right)$, $\varepsilon\left(\mathrm{Li}^{+}, \mathrm{OH}^{-}\right), \varepsilon\left(\mathrm{Na}^{+}, \mathrm{OH}^{-}\right)$and $\varepsilon\left(\mathrm{K}^{+}, \mathrm{OH}^{-}\right)$derived in this study. The ionization constant of water, for example, in $\mathrm{NaCl}$ media, can be expressed as:

$\mathrm{H}_{2} \mathrm{O}(\mathrm{l})=\mathrm{H}^{+}+\mathrm{OH}^{-} \quad(28)$

$\log \mathrm{K}^{\circ}{ }_{\mathrm{w}}=\log \mathrm{Q}_{\mathrm{w}}-2 \mathrm{D}+\varepsilon\left(\mathrm{H}^{+}, \mathrm{Cl}^{-}\right) \mathrm{m}_{\mathrm{NaCl}}+\varepsilon\left(\mathrm{Na}^{+}, \mathrm{OH}^{-}\right)$

$\mathrm{m}_{\mathrm{NaCl}}-\log \mathrm{a}_{\mathrm{H}_{2} \mathrm{O}}$

where $\log \mathrm{K}^{\circ}{ }_{\mathrm{w}}$ is the ionization constant of water at infinite dilution, $\log \mathrm{Q}_{\mathrm{w}}$ the apparent ionization constant of water at a certain ionic strength. Eq. (29) can be recast as:

$\log \mathrm{Q}_{\mathrm{w}}=\log \mathrm{K}_{\mathrm{w}}^{\circ}+2 \mathrm{D}-\varepsilon\left(\mathrm{H}^{+}, \mathrm{Cl}^{-}\right) \mathrm{m}_{\mathrm{NaCl}}-\varepsilon\left(\mathrm{Na}^{+}, \mathrm{OH}^{-}\right)$

$\mathrm{m}_{\mathrm{NaCl}}+\log \mathrm{a}_{\mathrm{H}_{2} \mathrm{O}}$

The activity of water in $\mathrm{NaCl}$ solutions is calculated from the osmotic coefficient $(\varphi)$ of the $\mathrm{NaCl}$ solutions with $\mathrm{NaCl}$ concentrations of interest,

$\log \mathrm{a}_{\mathrm{H}_{2} \mathrm{O}}=-2 \mathrm{~m}_{\mathrm{NaCl}} \varphi /[(\ln 10) \times 55.51]$

and the osmotic coefficients of $\mathrm{NaCl}$ solutions are from Gibbard et al. [25] at $\mathrm{T}<75^{\circ} \mathrm{C}$, and from Liu and Lindsay [42] at $\mathrm{T} \geq 75^{\circ} \mathrm{C}$.

According to Eq. (30) and $\log \mathrm{K}^{\circ}{ }_{\mathrm{w}}$ from Busey and Mesmer [83], the apparent dissociation quotients of water in $\mathrm{LiCl}, \mathrm{NaCl}$ and $\mathrm{KCl}$ media with ionic strength up to $5.0 \mathrm{~m}$ are predicted based the interaction coefficients recommended by this study. In calculations, the osmotic coefficients of $\mathrm{LiCl}$ solutions at $25^{\circ} \mathrm{C}$ are from Robinson and Stokes [22], and the osmotic coefficients of $\mathrm{KCl}$ solutions are assumed to be the same as those of $\mathrm{NaCl}$ solutions. The predicted values are compared with the experimentally determined values (Table 10). As indicated in Table 


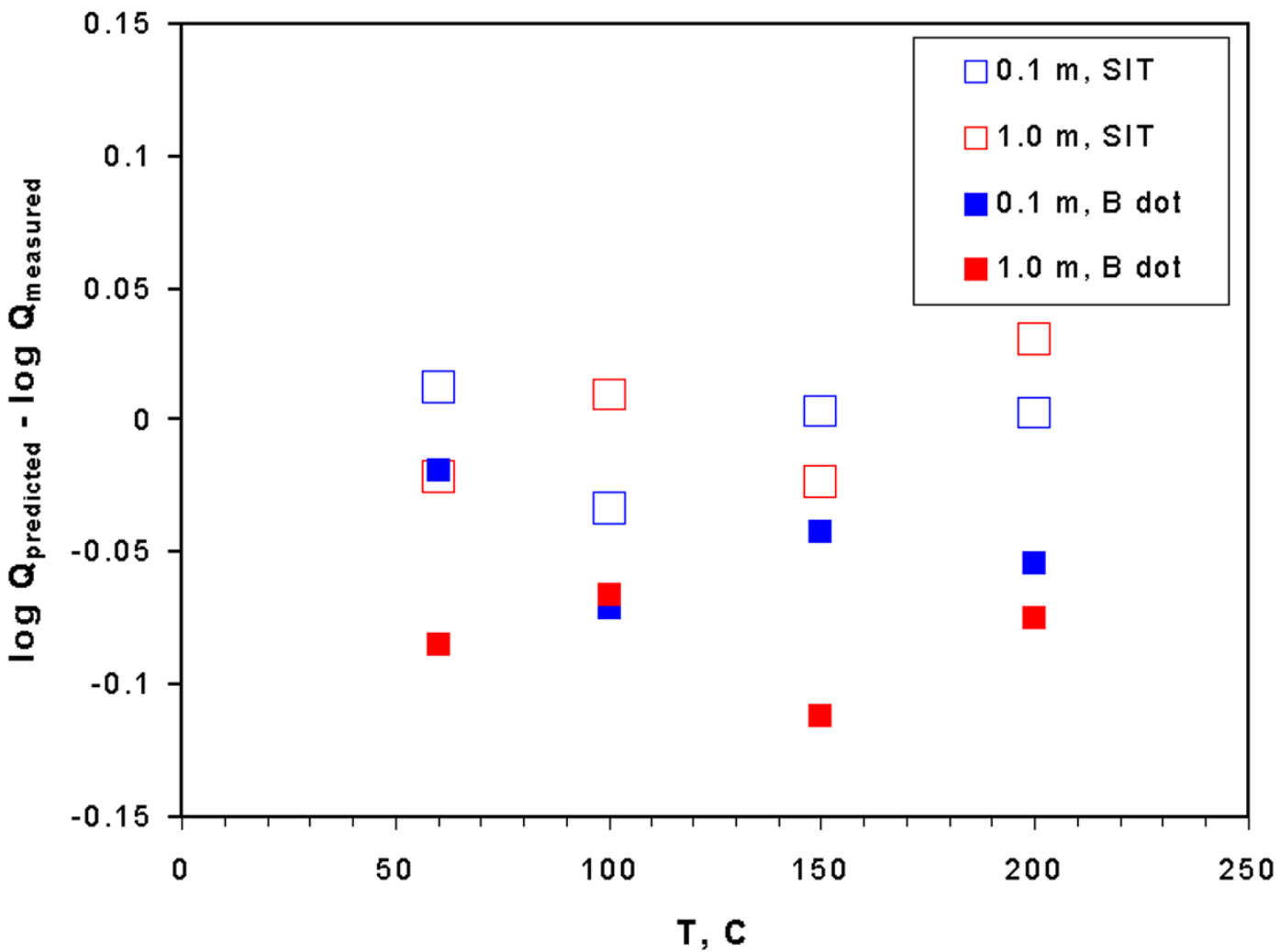

Figure 4

A plot showing the comparison of predicted solubility quotients of brucite with those determined by experimental studies in $\mathrm{NaCl}$ at elevated temperatures. Experimental solubility quotients are at $60^{\circ} \mathrm{C}, 100^{\circ} \mathrm{C}, 150^{\circ} \mathrm{C}$, and $200^{\circ} \mathrm{C}$ are from Brown et al. 80 .

10 , although the predicted values are not exactly within experimental uncertainty in some cases (the predicted values are within the experimental uncertainty of \pm 0.05 in Chen et al. [87]), the sigma values are better than 0.05 . Agreement within \pm 0.05 logarithmic unit is classified as very good agreement, even in the systems that can be studies experimentally without difficulty [89]. As demonstrated by Wang et al. [2], dissociation quotients of water even at $25^{\circ} \mathrm{C}$ obtained by various researchers can differ by more than \pm 0.05 in logarithmic unit. The above comparison demonstrates that predicted dissociation quotients of water in $\mathrm{NaCl}$ and $\mathrm{KCl}$ solutions are in satisfactory agreement with those determined by experimental studies. In addition, by using $\varepsilon\left(\mathrm{H}^{+}, \mathrm{Cl}^{-}\right)$and $\varepsilon\left(\mathrm{K}^{+}, \mathrm{OH}^{-}\right)$derived in this study, the dissociation quotients of heavy water $\left(\mathrm{D}_{2} \mathrm{O}\right)$ in $0.204 \mathrm{~m} \mathrm{KCl}$ solution are also predicted from $50^{\circ} \mathrm{C}$ to $200^{\circ} \mathrm{C}$, and compared with experimental data of Mesmer and Herting [86]. The predicted values are also satisfactory as indicated by a sigma value of 0.027 .

Similarly, the experimental dissociation quotients of acetic acid in $\mathrm{NaCl}$ solutions at $25^{\circ} \mathrm{C}$ are compared with val- ues predicted by using $\varepsilon\left(\mathrm{H}^{+}, \mathrm{Cl}^{-}\right)$and $\varepsilon\left(\mathrm{Na}^{+}, \mathrm{Ac}^{-}\right)$ estimated in this study. In the comparison, $\log \mathrm{K}^{\circ}$ at $25^{\circ} \mathrm{C}$ is from Partanen and Covington [39]. The results in Table 11 indicate that predicted values agree with experimental values better than 0.020 in terms of sigma value.

To test the interaction coefficient of $\varepsilon\left(\mathrm{GdAc}^{2+}, \mathrm{Cl}^{-}\right)$, $\varepsilon\left(\mathrm{GdAc}^{2+}, \mathrm{Cl}^{-}\right)$is used as an analog to $\varepsilon\left(\mathrm{LaAc}^{2+}, \mathrm{Cl}^{-}\right)$, $\varepsilon\left(\mathrm{NdAc}^{2+}, \mathrm{Cl}^{-}\right)$and $\varepsilon\left(\mathrm{YbAc}^{2+}, \mathrm{Cl}^{-}\right)$to predict the first formation quotients of $\mathrm{La}^{3+}, \mathrm{Nd}^{3+}$, and $\mathrm{Yb}^{3+}$ with $\mathrm{Ac}$ up to $70^{\circ} \mathrm{C}\left(\log \mathrm{Q}_{1}\right)$, and then compare them with the respective experimental values of Ding and Wood [36]. It should be noted that those experimental results have not been employed to estimate any interaction coefficients. In calculations, the respective $\log \beta^{\circ}{ }_{1}$ at infinite dilution are from Ding and Wood [36], and $\varepsilon\left(\mathrm{Gd}^{3+}, \mathrm{Cl}^{-}\right)$is utilized as an analog to $\varepsilon\left(\mathrm{La}^{3+}, \mathrm{Cl}^{-}\right), \varepsilon\left(\mathrm{Nd}^{3+}, \mathrm{Cl}^{-}\right)$, and $\varepsilon\left(\mathrm{Yb}^{3+}, \mathrm{Cl}^{-}\right)$. The comparison indicates that predicted values are in very good agreement with experimental values. For $\log \mathrm{Q}_{1}$ of $\mathrm{LaAc}^{2+}$, the maximum experimental uncertainty is 0.32 in comparison with the sigma value of 0.11 (Table 12). For $\log \mathrm{Q}_{1}$ of $\mathrm{NdAc}^{2+}$, the maximum experimental uncertainty 
Table 10: Comparison of dissociation quotient of water $\left(\log \mathbf{Q}_{w}\right)$ predicted by using SIT with experimental values

\begin{tabular}{|c|c|}
\hline Experimental Data Sets* & Sigma Value $\sigma$ \\
\hline $\begin{array}{l}\text { Harned and Owen }[84]^{\mathrm{A}} \text { : in } 0.1 \mathrm{I}-3.0 \mathrm{~m}_{\mathrm{LiCl}} \text { at } \mathrm{T}= \\
25^{\circ} \mathrm{C}\end{array}$ & 0.023 \\
\hline $\begin{array}{l}\text { Harned and Owen }[84]^{\mathrm{A}} \text { : in } 0.1 \mathrm{I}-3.0 \mathrm{~m}_{\mathrm{KCl}} \text { at } \mathrm{T}= \\
25^{\circ} \mathrm{C}\end{array}$ & 0.034 \\
\hline $\begin{array}{l}\text { Harned and Owen }[84]^{\mathrm{A}} \text { : in } 0.1 \mathrm{I}-3.0 \mathrm{~m}_{\mathrm{NaCl}} \text { at } \mathrm{T}= \\
25^{\circ} \mathrm{C}\end{array}$ & 0.009 \\
\hline Mesmer et al. $[85]^{\mathrm{B}}$ : in $1.0 \mathrm{~m}_{\mathrm{KCl}}$ at $\mathrm{T}=25^{\circ} \mathrm{C}-200^{\circ} \mathrm{C}$ & 0.038 \\
\hline $\begin{array}{l}\text { Busey and Mesmer [83 }]^{\mathrm{B}} \text { : in } 0.1-5.0 \mathrm{~m}_{\mathrm{NaCl}} \text { at } \mathrm{T}= \\
25^{\circ} \mathrm{C}-200^{\circ} \mathrm{C}\end{array}$ & 0.049 \\
\hline $\begin{array}{l}\text { Mesmer and Herting [86 }{ }^{\mathrm{B}} \text { (heavy water): in } 0.204 \\
\mathrm{~m}_{\mathrm{KCl}} \text { at } \mathrm{T}=50^{\circ} \mathrm{C}-200^{\circ} \mathrm{C}\end{array}$ & 0.027 \\
\hline Chen et al. [87] $\mathrm{C}$ : in $0.1-5.0 \mathrm{~m}_{\mathrm{NaCl}}$ at $\mathrm{T}=25^{\circ} \mathrm{C}$ & 0.04 \\
\hline
\end{tabular}

* Experimental data sets are listed in chronological order.

A Experimental data set precise to three decimal places, cited in Baes and Mesmer [88].

Experimental data set precise to three decimal places.

${ }^{C}$ Experimental data set precise to two decimal places.

is 0.27 in comparison with the sigma value of 0.07 (Table 12). For $\log \mathrm{Q}_{1}$ of $\mathrm{YbAc}^{2+}$, the maximum experimental uncertainty is 0.14 in comparison with the sigma value of 0.11 (Table 12)

\section{Applications}

It is well known that the determination of $\mathrm{pH}$ or hydrogen ion concentrations $(\mathrm{pcH})$ is important and problematic at $100^{\circ} \mathrm{C}$ and higher temperatures because of the inapplicability of glass electrodes under these conditions. The above examples of model verification may point to the potential of using the solubility of brucite as a $\mathrm{pH}(\mathrm{pcH})$ buffer/sensor in experimental studies in $\mathrm{NaCl}$ solutions up to $5.0 \mathrm{~m}$ or up to the saturation of halite at temperatures up to $200^{\circ} \mathrm{C}$. The advantages in using the brucite solubility as a $\mathrm{pH}(\mathrm{pcH})$ buffer/sensor include (1) its relatively fast kinetics to reach solubility equilibrium even at the room temperature [e.g., $[79,80]]$, and (2) concentrations of magnesium are present at such a level that they can be analyzed with high precision by using the modern analytical instruments such as ICP-AES.

Table I I: Comparison of dissociation quotient of acetic acid (log Q) in $\mathrm{NaCl}$ solutions predicted by using SIT with experimental values

\begin{tabular}{lc}
\hline \multicolumn{1}{c}{ Experimental Data Sets* } & Sigma Value $\sigma$ \\
\hline Belevantsev et al. [90] $\mathrm{A}$ : in $1.0-4.0 \mathrm{M}_{\mathrm{NaCl}}$ at $\mathrm{T}=25^{\circ} \mathrm{C}$ & 0.02 \\
Robertis et al. [9I] $]^{\mathrm{A}}$ in $0.04-1.0 \mathrm{M}_{\mathrm{NaCl}}$ at T $=25^{\circ} \mathrm{C}$ & 0.01 \\
Chen et al. [87] $\mathrm{B}$ in $0.1-5.0 \mathrm{~m}_{\mathrm{NaCl}}$ at $\mathrm{T}=25^{\circ} \mathrm{C}$ & 0.019
\end{tabular}

*Experimental data sets are listed in chronological order.

Experimental data set precise to two decimal places.

${ }^{B}$ Experimental data set precise to three decimal places.
Table 12: Comparison of formation quotients of REE with acetate $\left(\log Q_{1}\right)$ in $\mathrm{NaCl}$ solutions predicted by using SIT with experimental values

\begin{tabular}{lc}
\hline Experimental Data Sets & Sigma Value $\sigma$ \\
\hline $\begin{array}{l}\text { Ding and Wood [36]: formation quotients of } \mathrm{LaAc}^{2+} \\
\text { in } 0.1-2.0 \mathrm{~m}_{\mathrm{NaCl}} \text { at } \mathrm{T}=25^{\circ} \mathrm{C}-70^{\circ} \mathrm{C}\end{array}$ & $0.1 \mathrm{I}$ \\
Ding and $\mathrm{Wood}[36]$ : formation quotients of $\mathrm{NdAc}^{2+}$ & 0.07 \\
in $0.1-2.0 \mathrm{~m}_{\mathrm{NaCl}}$ at $\mathrm{T}=25^{\circ} \mathrm{C}-70^{\circ} \mathrm{C}$ & \\
Ding and $\mathrm{Wood}[36]:$ formation quotients of $\mathrm{YbAc}^{2+}$ & 0.11 \\
in $0.1-2.0 \mathrm{~m}_{\mathrm{NaCl}}$ at $\mathrm{T}=25^{\circ} \mathrm{C}-70^{\circ} \mathrm{C}$ &
\end{tabular}

The governing equations for the solubility of brucite as the $\mathrm{pH}(\mathrm{pcH})$ buffer/sensor are Reactions (23) and (28) presented above in combination with the following charge and mass balance equations:

$2 \mathrm{~m}_{\mathrm{Mg}^{2+}}+\mathrm{m}_{\mathrm{MgOH}^{+}}+\mathrm{m}_{\mathrm{H}^{+}}=\mathrm{m}_{\mathrm{OH}^{-}}$

$\Sigma \mathrm{m}_{\mathrm{Mg}}=\mathrm{m}_{\mathrm{Mg}^{2+}}+\mathrm{m}_{\mathrm{MgOH}^{+}}$

The first hydrolysis quotients of magnesium(II) at elevated temperatures in $\mathrm{NaCl}$ solutions can be taken from Palmer and Wesolowski [92]:

$\mathrm{Mg}^{2+}+\mathrm{H}_{2} \mathrm{O}=\mathrm{MgOH}^{+}+\mathrm{H}^{+}$

To facilitate such applications, solubility quotients of brucite in $0.1-5.0 \mathrm{~m} \mathrm{NaCl}$ solutions represented by Eq. (25) are predicted from $100^{\circ} \mathrm{C}$ to $200^{\circ} \mathrm{C}$ at $\mathrm{P}_{\mathrm{SAT}}$ at the increment of $50^{\circ} \mathrm{C}$ according to the interaction coefficients evaluated by this study (Table 13). When using brucite solubility as a $\mathrm{pH}$ buffer/sensor, it is advisable to utilize brucite of high-purity, because there are impurities in some commercially available brucite, which can result in non-stoichiometric dissolution, as noticed by Altmaier et al. [79] at $25^{\circ} \mathrm{C}$.

\section{Conclusion}

The SIT model, because of its less parameterized nature, is inherently less precise in reproduction of highly precise activity (and osmotic) coefficient data than the more parameterized Pitzer model, especially in high ionic strength region, even though it is advantageous in its mathematical simplicity. Therefore, the Pitzer formalism is the preferred method in treatment of activity (and osmotic) coefficients and other thermodynamic properties with high precision. However, in treatment of equilibrium constants, which are less precise than activity (and osmotic) coefficients in nature, the SIT model has the reasonable accuracy comparable to the Pitzer formalism. Hence, the SIT model would be a reliable method in evaluation of medium effects on thermodynamics, including its usage in extrapolation of equilibrium constants to infi- 
Table 13: Predicted solubility quotient of $\mathrm{Mg}(\mathrm{OH})_{2}(\mathrm{~s})\left(\log \mathrm{Q}_{2}\right)$ in $\mathrm{NaCl}$ solutions at $100^{\circ} \mathrm{C}, 150^{\circ} \mathrm{C}$ and $200^{\circ} \mathrm{C}$ at saturated vapor pressures

\begin{tabular}{|c|c|c|}
\hline Temperature, $\mathrm{C}$ & $\mathrm{m}_{\mathrm{NaCl}}$ & $\log Q_{2}$ \\
\hline \multirow[t]{11}{*}{100} & 0.1 & 13.44 \\
\hline & 0.5 & 13.60 \\
\hline & 1.0 & 13.68 \\
\hline & 1.5 & 13.77 \\
\hline & 2.0 & 13.82 \\
\hline & 2.5 & 13.86 \\
\hline & 3.0 & 13.90 \\
\hline & 3.5 & 13.94 \\
\hline & 4.0 & 13.98 \\
\hline & 4.5 & 14.02 \\
\hline & 5.0 & 14.05 \\
\hline \multirow[t]{11}{*}{150} & 0.1 & 11.63 \\
\hline & 0.5 & 11.80 \\
\hline & 1.0 & 11.88 \\
\hline & 1.5 & 11.97 \\
\hline & 2.0 & 12.02 \\
\hline & 2.5 & 12.06 \\
\hline & 3.0 & 12.09 \\
\hline & 3.5 & 12.12 \\
\hline & 4.0 & 12.16 \\
\hline & 4.5 & 12.19 \\
\hline & 5.0 & 12.22 \\
\hline \multirow[t]{11}{*}{200} & 0.1 & 10.22 \\
\hline & 0.5 & 10.42 \\
\hline & 1.0 & $10.5 \mid$ \\
\hline & 1.5 & 10.59 \\
\hline & 2.0 & 10.64 \\
\hline & 2.5 & 10.67 \\
\hline & 3.0 & 10.70 \\
\hline & 3.5 & 10.73 \\
\hline & 4.0 & 10.75 \\
\hline & 4.5 & 10.77 \\
\hline & 5.0 & 10.80 \\
\hline
\end{tabular}

nite dilution, at elevated temperatures. It would be especially useful to experimental aqueous geochemists and chemists to assess the medium effect beyond ionic strength of $\sim 1.0 \mathrm{~m}$, which is the limit valid to the currently often employed B dot equation.

\section{Acknowledgements}

Sandia National Laboratories is a multiprogram laboratory operated by Sandia Corporation, a Lockheed Martin Company, for the United States Department of Energy's National Nuclear Security Administration under Contract DE-AC04-94AL85000. The author thanks two anonymous reviewers for their constructive and helpful criticism, which led to the substantial improvement in presentation. The author also wishes to extend his thanks to the Editor-in-Chief, Dr. Scott Wood, for his editorial efforts.

\section{References}

I. Grenthe I, Plyasunov AV, Spahiu K: Chapter IX Estimation of Medium Effects on Thermodynamic Data. In Modeling in
Aquatic Chemistry Edited by: Grenthe I, Puigdomenech I. Issy-lesMoulineaux, France: OECD Nuclear Energy Agency; 1997:325-426.

2. Wang MS, Zhang Y, Muhammed M: Hydrometallurgy 1997, 45:21-36.

3. Pitzer KS: Journal of Physical Chemistry 1973, 77:268-277.

4. Brønsted JN: Journal of American Chemical Society 1922, 44:877-989.

5. Guggenheim EA: Philosophy Magazine 1935, 19:588-643.

6. Scatchard G: Equilibrium in Solutions: Surface and Colloid Chemistry Cambridge, MA: Harvard University Press; 1976.

7. Bromley LA: American Institute of Chemical Engineering Journal 1973, 19:3|3-320.

8. Helgeson HC, Kirkham DH, Flowers GC: American Journal of Science |98|, $281:|249-| 5 \mid 6$.

9. Helgeson HC: American Journal of Science 1969, 267:729-804.

10. Wolery TJ: EQ3NR, A Computer Program for Geochemical Aqueous Speciation-Solubility Calculations: Theoretical Manual, User's Guide, and Related Documentation (Version7.0). UCRL-MA-I I0662 PT III. Livermore CA: Lawrence Livermore National Laboratory; 1992.

II. Pitzer KS: Ion interaction approach: Theory and data correlation. In Activity Coefficients in Electrolyte Solutions 2nd edition. Edited by: Pitzer KS. Boca Raton, Florida, USA: CRC Press; 1991:75-I53.

12. Ciavatta L: Annali di Chemica (Rome) 1980, 70:55I-567.

13. Ciavatta L: Annali di Chemica (Rome) 1990, 80:255-263.

14. Grenthe I, Fuger J, Konings RJM, Lemire RJ, Muller AB, Nguyen-Trung $\mathrm{C}$, Wanner H: Chemical Thermodynamics of Uranium New York: Elsevier Science Publishers; 1992.

15. Guillaumont R, Fanghanel T, Fuger J, Grenthe I, Neck V, Palmer DA, Rand MH: Update on the Chemical Thermodynamics of Uranium, Neptunium, Plutonium, Americium and Technetium New York: Elsevier Science Publishers; 2003.

16. Thoenen T, Hummel W: Application of the Bronsted-Guggenheim-Scatchard specific ion interaction theory to the concentration dependence of complexation constants in $\mathrm{NaCl}$ solutions up to the saturation of halite [abstract]. Journal of Conference Abstracts 2000, 5(2):997.

17. Giffaut E, Vitorge P, Capdevila H: Journal of Alloys and Compounds I994, 2 |3/2 | 4:278-285.

18. Bretti C, Foti C, Sammartano S: Chemical Speciation and Bioavailability 2004, 16:105-I10.

19. Vasil'ev VP: Russian Journal of Inorganic Chemistry 1962, 7:924-927.

20. Plyasunova N, Zhang Y, Muhammed M: Hydrometallurgy 1998, 48:153-169.

21. Bradley DJ, Pitzer KS: Journal of Physical Chemistry 1979, 83:1599-1603.

22. Robinson RA, Stokes RH: Electrolyte Solutions London: Butterworths Scientific Publications; 1959.

23. Greeley RS, Smith WT Jr, Lietzke MH, Stoughton RW: Journal of Physical Chemistry 1960, 64: I445-I448.

24. Holmes HF, Busey RH, Simonson JM, Mesmer RE: Journal of Chemical Thermodynamics 1987, 19:863-890.

25. Gibbard HF Jr, Scatchard G, Rousseau RA, Creek JL: Journal of Chemical and Engineering Data 1974, 19:28I-288.

26. Holmes HF, Busey RH, Simonson JM, Mesmer RE: Journal of Chemical Thermodynamics 1994, 26:27I-298.

27. Holmes HF, Mesmer RE: Journal of Chemical Thermodynamics 1996 28: I 325-I358.

28. Roy RN, Gregory DR, Roy LN, Pierrot D, Millero FJ: Journal of Solution Chemistry 2000, 29:619-631.

29. Pitzer KS, Peterson JR, Silvester LF: Journal of Solution Chemistry I978, 7:45-56.

30. Criss CM, Millero FJ: Journal of Solution Chemistry 1999, 28:849-864.

31. Pitzer KS, Mayorga G: Journal of Physical Chemistry 1973, 77:2300-2308.

32. Ananthaswamy J, Atkinson G: Journal of Chemical and Engineering Data 1984, 29:8I-87.

33. Roy RN, Roy LN, Gregory DR, VanLanduyt AJ, Pierrot D, Millero F]: Journal of Solution Chemistry 2000, 29: I I I I-1227.

34. Roy RN, Roy LN, Gregory DR, VanLanduyt AJ, Pierrot D, Millero FJ: Journal of Chemical and Engineering Data 200I, 46:55I-556.

35. Holmes HF, Mesmer RE: Journal of Chemical Thermodynamics 1998 , 30:3II-326.

36. Ding R, Wood SA: The aqueous geochemistry of the rare earth elements and yttrium. Part $\mathbf{X}$. Potentiometric determination of stability constants of acetate complexes of $\mathrm{La}^{3+}, \mathrm{Nd}^{3+}$, $\mathbf{G d}^{3+}$ and $\mathbf{Y b}^{3+}$ at $25-70^{\circ} \mathbf{C}$ and I bar. In Water-Rock Interactions, Ore Deposits, and Environmental Geochemistry: A Tribute to David A. Crerar, The Geochemical Society Special Publication No. 7 Edited by: Hell- 
mann R, Wood SA. St. Louis. MO, USA: The Geochemical Society; 2002:209-227.

37. Kiss AV, Urmánczy A: Z Phys Chem A 1934, 171:257-267.

38. Mesmer RE, Patterson CS, Busey RH, Holmes HF: Journal of Physical Chemistry 1989, 93:7483-7490.

39. Partanen Jl, Covington AK: Journal of Chemical and Engineering Data 2003, 48:797-807.

40. Johnston J, Grove C: Journal of American Chemical Society 193I, 53:3976-399|

41. Seward TM: Geochimica et Cosmochimica Acta 1976, 40:|329-|34|.

42. Liu C, Lindsay WT Jr: Journal of Solution Chemistry 1972, I:45-69.

43. Christov C, Moller N: Geochimica et Cosmochimica Acta 2004, 68:37I7-3739.

44. Lobo VMM: Handbook of Electrolyte Solutions, Part A New York: Elsevier; 1989.

45. Lobo VMM, Quaresma JL: Handbook of Electrolyte Solutions, Part B New York: Elsevier; 1989.

46. Robinson RA, Harned HS: Chemical Reviews 1941, 28:419-476.

47. Bates RG, Bower VE: Journal of Research of the National Bureau of Standards 1954, 53:283-290.

48. Roy RN, Rice SA, Vogel KM, Roy LN: Journal of Physical Chemistry 1990, 94:7706-7710.

49. Busey RH, Holmes HF, Mesmer RE: Journal of Chemical Thermodynamics 1984, 16:343-372.

50. White DR Jr, Robinson RA, Bates RG: Journal of Solution Chemistry 1980, 9:457-465

5I. Pan C-F: Journal of Chemical and Engineering Data 1977, 22:234-237.

52. Goldberg RN, Nuttall RL: Journal of Physical Chemistry Reference Data 1978, 7:263-310.

53. Rard JA, Mille DG: Journal of Chemical and Engineering Data 198I, 26:38-43.

54. Wang P-M, Pitzer KS, Simonson JM: Journal of Physical and Chemical Reference Data 1998, 27:971-991.

55. El Guendouzi M, Dinane A, Mounir A: Journal of Chemical Thermodynamics 200I, 33:1059-1072.

56. McLeod HG, Gordon AR: Journal of American Chemical Society 1945, 68:58-60.

57. Robinson RA: Transactions of Faraday Society 1940, 36:733-748.

58. Stokes RH: Transactions of Faraday Society 1948, 44:295-307.

59. Shedlovsky RH: Journal of American Chemical Society 1948, 72:3680-3682.

60. Staples BS, Nuttall RH: Journal of Physical and Chemical Reference Data 1977, 6:385-407.

61. Rard JA, Clegg RH: Journal of Chemical Engineering Data 1997 , 42:819-849.

62. Gruszkiewicz MS, Simonson JM: Journal of Chemical Thermodynamics 2005, 37:906-930.

63. Harned HS, Åkerlöf G: Physik Z 1926, 27:4| I-448.

64. Phillips BA, Watson GM, Felsing WA: Journal of American Chemical Society 1942, 64:244-247.

65. Longhi P, Mussini T, Vaghi E: Journal of Chemical Thermodynamics 1975, 7:767-776

66. Tippetts EA, Newton RF: Journal of American Chemical Society 1934:1675-1680

67. Ardizzone S, Longhi P, Mussini T, Rondinini S: Journal of Chemical Thermodynamics 1976, 8:557-564.

68. Mason CM: Journal of American Chemical Society 194I, 63:220-223.

69. Spedding FH, Weber HO, Saeger VW, Petheram HH, Rard JA, Habenschuss A: Journal of Chemical and Engineering Data 1976, 2I:34I-360.

70. Kangro W, Groeneveld A: Z Phys Chem Neue Folge 1962, 32: I I0-126.

7I. Hamer WJ, Wu Y-C: Journal of Physical and Chemical Reference Data 1972, I:1047-1099.

72. Harned HS: Journal of American Chemical Society 1925, 47:676-684

73. Åkerlöf G, Kegeles G: Journal of American Chemical Society 1940, 62:620-640

74. Knobel M: Journal of American Chemical Society 1923, 45:70-76.

75. Scatchard G: Journal of American Chemical Society 1925, 47:648-66I.

76. Harned HS, Cook MA: Journal of American Chemical Society 1937, 59:496-500.

77. Harned HS, Schupp OE: Journal of American Chemical Society 1930, 52:3886-3892.

78. Robinson RA, Stokes RH: Transactions of Faraday Society 1949, 45:612-624.

79. Altmaier M, Metz V, Neck V, Müller R, Fanghänel Th: Geochimica et Cosmochimica Acta 2003, 67:3595-360I.
80. Brown PL, Drummond SE, Palmer DA: Journal of Chemical Society, Dalton Transactions 1996:307I-3075.

81. Gammons CH, Seward TM: Geochimica et Cosmochimica Acta 1996 60:4295-43II.

82. Mesmer RE, Palmer DA, Simonson JM: Ion association at high temperatures and pressure. In Activity Coefficients in Electrolyte Solutions 2nd edition. Edited by: Pitzer KS. Boca Raton, Florida, USA: CRC Press; 1991:491-528.

83. Busey RH, Mesmer RE: Journal of Chemical and Engineering Data 1978 , 22: $175-176$.

84. Harned HS, Owen BB: The Physical Chemistry of Electrolyte Solutions 3rd edition. New York: Reihold Publishing Corporation; 1958.

85. Mesmer RE, Baes CF Jr, Sweeton FH: Journal of Physical Chemistry 1970, 74: $1937-1942$.

86. Mesmer RE, Herting DL: Journal of Solution Chemistry 1978, 7:90 I-9I3.

87. Chen J-F, Xia Y-X, Choppin G: Analytical Chemistry 1996, 68:3973-3978.

88. Baes CF Jr, Mesmer RE: The Hydrolysis of Cations Malabar, Florida, USA: Krieger Publishing Company; 1976.

89. Beck MT, Nagypal I: Chemistry of Complex Equilibria (translated from Hungary to English by Williams, D.R.) New York: Ellis Horwood; 1990.

90. Belevantsev VI, Mironov IV, Peshchevitskii BI: Zh Neoganicheskoi Khimii 1982, 27:53-57.

91. Robertis AD, Stefano CD, Rigano C, Sammartano S, Scarcella RJ: Journal of Chemical Research (Spain) 1985:42.

92. Palmer DA, Wesolowski DJ: Journal of Solution Chemistry 1997, 20:217-232
Publish with Bio Med Central and every scientist can read your work free of charge

"BioMed Central will be the most significant development for disseminating the results of biomedical research in our lifetime. " Sir Paul Nurse, Cancer Research UK

Your research papers will be:

- available free of charge to the entire biomedical community

- peer reviewed and published immediately upon acceptance

- cited in PubMed and archived on PubMed Central

- yours - you keep the copyright
BioMedcentral 